\title{
Attachment and Detachment of Living Microorganisms Using a Potential-Controlled Electrode
}

\author{
Sumihiro Koyama • Masa-aki Konishi • Yukari Ohta • \\ Tetsuya Miwa • Yuji Hatada • Takashi Toyofuku • \\ Tadashi Maruyama Yuichi Nogi $\cdot$ Chiaki Kato • \\ Taishi Tsubouchi
}

Received: 2 May 2012 / Accepted: 3 February 2013 / Published online: 19 February 2013

(C) The Author(s) 2013. This article is published with open access at Springerlink.com

\begin{abstract}
We developed an electrical modulation method for attachment and detachment of microorganisms. Living microorganisms suspended in non-nutritive media such as PBS(-) and artificial seawater were attracted by and selectively attached to indium tin oxide (ITO)/glass electrode regions to which a negative potential was applied. The microorganisms suspended in LB medium and glucose solution were not attracted to the ITO electrode. Dead microorganisms were not attracted to the ITO electrode. The living microorganisms were retrieved after detachment from the ITO electrode by application of a high-frequency triangular wave potential. When we applied this method to separate microorganisms from deep-sea sediment, bacteria belonging to 19 phyla and 23 classes were collected without undesirable high molecular weight contaminants such as humic acids. At the phylum and class level, respectively, 95 and $87 \%$ of the phylotypes among electrically retrieved bacteria were common to the gene clones from the direct sediment DNA extraction. This technique is a novel useful method to prepare bacterial cells in a single population or a community for metagenomic analyses.
\end{abstract}

S. Koyama $(\bowtie) \cdot$ M.-a. Konishi $\cdot$ Y. Ohta $\cdot$ Y. Hatada $\cdot$

T. Toyofuku $\cdot$ T. Maruyama $\cdot$ Y. Nogi $\cdot$ C. Kato $\cdot$ T. Tsubouchi Institute of Biogeosciences,

Japan Agency for Marine-Earth Science and Technology,

2-15 Natsushima-cho,

Yokosuka, Kanagawa 237-0061, Japan

e-mail: skoyama@jamstec.go.jp

T. Miwa

Marine Technology and Engineering Center,

Japan Agency for Marine-Earth Science and Technology,

2-15 Natsushima-cho,

Yokosuka, Kanagawa 237-0061, Japan
Keywords Electrical modulation - Electrical attachment . Electrical detachment $\cdot$ Soil microorganisms $\cdot$ Deep-sea microorganisms $\cdot$ Escherichia coli

\section{Introduction}

Microorganisms in soil and sediments are rich sources of novel therapeutic compounds such as antibiotics (Raaijmakers et al. 1997), anticancer agents (Shen et al. 2001), and immunosuppressants (Skoko et al. 2005), as well as a wide range of biotechnologically valuable products (Hatada et al. 2011; Ohta and Hatada 2006). However, the majority of microorganisms present in sediment and soil cannot be cultured under conventional laboratory conditions (Rajendhran and Gunasekaran 2008).

Metagenomics has been developed over the past decade to clarify a previously unknown diversity of microorganisms on the one hand; on the other hand, it has been driven by the increasing biotechnological demand for novel enzymes and biomolecules (Rajendhran and Gunasekaran 2008; Simon and Daniel 2011). Analysis of DNA directly extracted from sediment and soil samples has paved the way to studying natural microbial communities without the need for cultivation. However, high DNA yields and purity are difficult to achieve due to the co-extraction of humic substances that inhibit downstream applications, such as polymerase chain reaction (PCR), restriction enzyme digestion, and DNA ligation (Roh et al. 2006). In indirect DNA extraction methods, microorganisms are separated from the sediment and soil samples prior to cell lysis. Higher molecular weight and purer environmental DNA is obtained from indirect cell lysis compared with direct protocols (Courtois et al. 2001; Gabor et al. 2003; Roh et al. 2006). However, it 
was reported that the DNA obtained is usually derived from only about 25 to $35 \%$ of the total number of microorganisms present in the soil and sediment samples (Rajendhran and Gunasekaran 2008). Various bacterial groups strongly attach to soil aggregates, which might bias the picture of the organization of the microbial community in the sample (Rajendhran and Gunasekaran 2008; Steffan et al. 1988).

Microbial single-cell isolation techniques have also been developed during the past decade for three major purposes: (1) to cultivate previously uncultured microbes, (2) to assess and monitor cell physiology and function, and (3) to screen for novel microbiological products such as enzymes and antibiotics (Brehm-Stecher and Johnson 2004; Broude 2011; Ishii et al. 2010). Microbial single-cell isolation techniques fall into five major categories (Ishii et al. 2010). The first is the dilution-to-extinction method, which is probably the simplest method to obtain single cells from heterogeneous populations and involves serial dilutions of a sample solution until only single cells remain (Button et al. 1993; Schut et al. 1993). The second is micromanipulation, which obtains single cells using a mechanical micromanipulator or an optical tweezer (Fröhlich and König 2000; Huber et al. 2000; Ishii et al. 2010). The trapped cells are subsequently used for cultivation or other analyses. The third is flow cytometry, which enables the rapid analysis of entire cell populations on the basis of single cell characteristics (Brehm-Stecher and Johnson 2004). Multiple characteristics including cell count, cell size or content, and responses to fluorescent probes diagnostic of cell function may be collected simultaneously in this method (Brehm-Stecher and Johnson 2004). The fourth is microfluidics, which isolates and incubates single cells of interest using a number of microflow channels (Fu et al. 1999; Hu et al. 2005). The fifth is compartmentalization of single cells, which are screened for potentially novel enzymes and for cultivation of yet-uncultured microbes (Bergquist et al. 2009; Bershtein and Tawfik 2008; Ishii et al. 2010; Link et al. 2007). However, it is extremely difficult to use these five techniques for direct assay of various living microorganisms in soil and/or sediment samples. Because the microorganisms adhere strongly to soil aggregates, it is difficult to separate them alive from the aggregates (Rajendhran and Gunasekaran 2008; Steffan et al. 1988).

In the present study, we demonstrated that a weak negative electric potential attracted living microorganisms to the electrode surface and that they were separated from sediment and soil particles. Furthermore, the electrically attached living microorganisms could be detached from the electrode by application of a high-frequency triangular wave potential. Using the electrical modulation technique, attachment and detachment of specifically positioned microorganisms can be modulated iteratively at the same positions on the electrode surface.

\section{Materials and Methods}

Soil and Deep-Sea Sediment Samples The surface layer of the deep-sea sediment sample was collected by the unmanned submersible Hyperdolphin (dive 1237; January 20, 2011; $\left.1,176 \mathrm{~m} ; 35^{\circ} 00.13^{\prime} \mathrm{N}, 139^{\circ} 13.51^{\prime} \mathrm{E}\right)$ from the seep area of Sagami Bay, Japan (Koyama and Aizawa 2000; Koyama et al. 2005). The garden soil sample was collected from the grapery of the Japan Agency for Marine-Earth Science and Technology.

Bacterial Strains and Media Bacillus halodurans, Shewanella violacea, Escherichia coli, Bacillus subtilis, Shewanella oneidensis, and Kocuria rosea were used as test microorganisms. B. halodurans $\mathrm{C}-125$, formerly known as Bacillus sp. strain C-125 (Takami and Horikoshi 1999), was thawed and recovered using Horikoshi I medium (Horikoshi and Akiba 1982) and then grown aerobically at $37{ }^{\circ} \mathrm{C}$ in Horikoshi I medium. S. violacea DSS12 ${ }^{\mathrm{T}}$, isolated from the Ryukyu trench, was thawed and regenerated using an autoclaved and $0.22-\mu \mathrm{m}$ filtered Marine broth 2216 medium (Difco Laboratories, Detroit, MI, USA) (Kato et al. 1995). The $S$. violacea cells were grown aerobically at $8{ }^{\circ} \mathrm{C}$ in the filtered Marine broth 2216 medium. E. coli $\left(\mathrm{JCM} 1649^{\mathrm{T}}\right)$ and B. subtilis $\left(\mathrm{JCM} 1465^{\mathrm{T}}\right)$ were grown aerobically at $37^{\circ} \mathrm{C}$ in Luria-Bertani (LB) medium (Difco Laboratories). S. oneidensis $\left(\mathrm{ATCC} 770550^{\mathrm{T}}\right.$ ) was grown aerobically at $30{ }^{\circ} \mathrm{C}$ in LB without $\mathrm{NaCl}(\mathrm{LB} \triangle \mathrm{N})$ medium containing tryptone $10.0 \mathrm{gl}^{-1}$ and yeast extract $5.0 \mathrm{gl}^{-1}$. K. rosea $\left(\mathrm{NBRC} 3768^{\mathrm{T}}\right)$ was grown aerobically at $30{ }^{\circ} \mathrm{C}$ in LBNG medium containing $\left(\mathrm{gl}^{-1}\right)$ : glucose, 30.0; tryptone, 10.0; yeast extract, 5.0; and $\mathrm{NaCl}$, 30.0. The glucose was sterilized separately and then added to the medium.

Electrode Preparation Patterned working electrodes were constructed by vacuum evaporation of indium tin oxide (ITO; $\mathrm{In}_{2} \mathrm{O}_{3} ; 10 \Omega / \mathrm{cm}^{2}$ ) and an insulator of silicon dioxide $\left(\mathrm{SiO}_{2}\right)$ onto $76 \times 26-\mathrm{mm}^{2}$ silica glass plates $(1 \mathrm{~mm}$ in thickness) (Geomatec Co., Ltd., Yokohama, Japan). The reticulated ITO electrode with arrayed square glass regions (Fig. 1) was described elsewhere (Koyama 2011). The microelectrode was formed by the plane ITO electrode fabricated with a coating of $\mathrm{SiO}_{2}$ (Fig. 1). The $76 \times 26-\mathrm{mm}^{2}$ - and 5-mm-thick silicon rubber plate with a hollow interior measuring $66 \times 16 \mathrm{~mm}^{2}$ was glued to the $76 \times 26-\mathrm{mm}^{2}$ slide glass by silicon bonding (Fig. 1). The patterned ITO/glass electrode was attached to the top of the silicon rubber box (Fig. 1). The fabricated silicon rubber box was housed in a sterile square plastic dish. A 12mm-diameter section of both the Pt ring counter electrode and $\mathrm{Ag} / \mathrm{AgCl}$ reference electrode was placed on the plastic lid of the square plastic dish (Fig. 1).

For viability analyses of the electrically detached microorganisms, we used a previously described three-electrode 


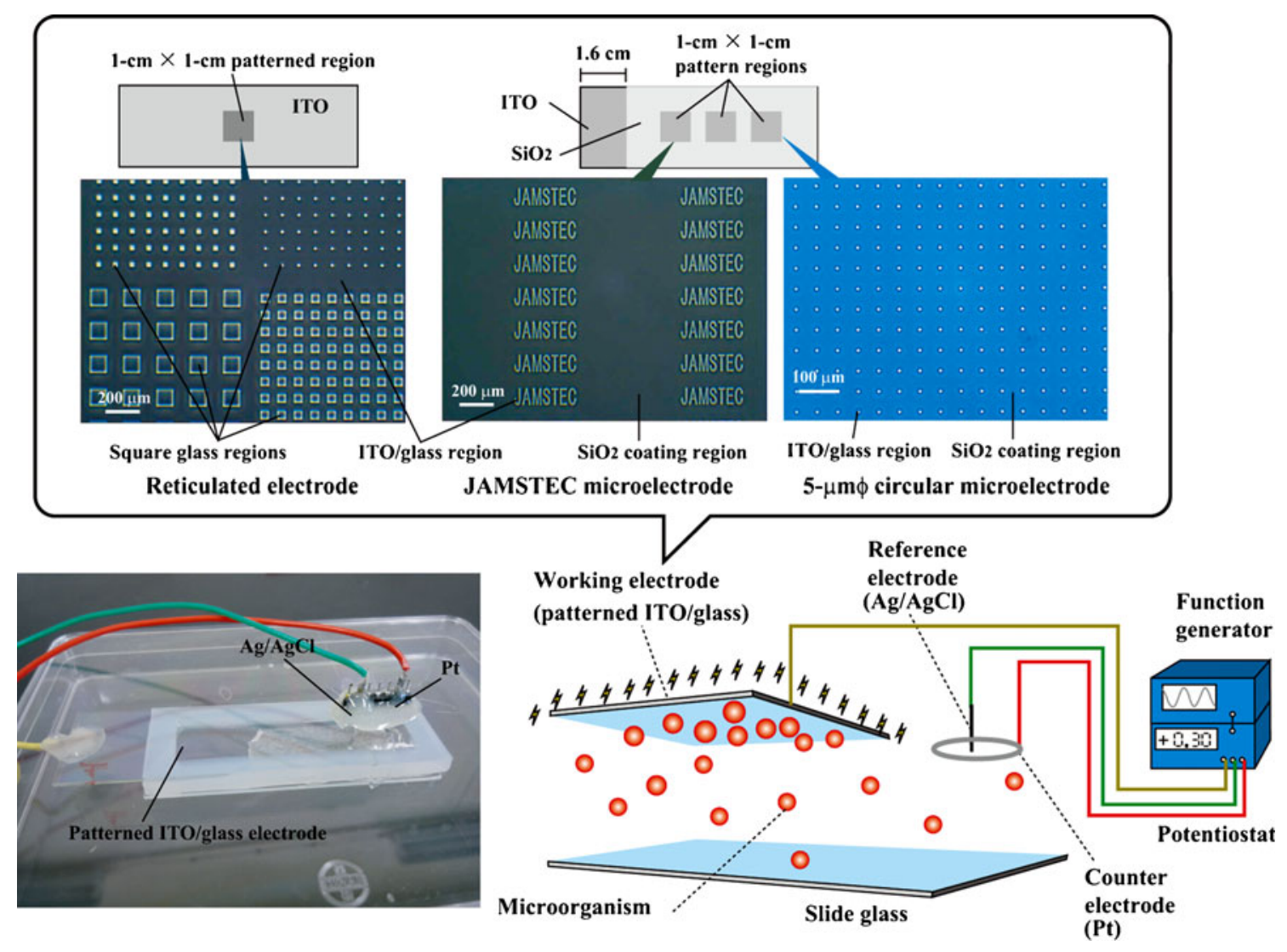

Fig. 1 Schematic illustration of a patterned indium tin oxide (ITO)/glass electrode culture system. The electrode potential is controlled with an $\mathrm{Ag} / \mathrm{AgCl}$ reference electrode through a potentiostat and a function generator

chamber system (Koyama 2011). The plastic chamber section of a Lab-tek chamber slide system (Cat. 177410, NalgeNunc International, Naperville, IL, USA) was glued to the patterned ITO/glass electrode with silicon bonding. The Pt counter electrode and $\mathrm{Ag} / \mathrm{AgCl}$ reference electrode were placed on the plastic lid of the chamber slide system.

Large electrode chamber devices were constructed for phylogenetic analyses of the microorganisms in sediment. A $110 \times 85-\mathrm{mm}^{2}$ - and 5-mm-thick silicon rubber plate with a hollow interior measuring $90 \times 65 \mathrm{~mm}^{2}$ was glued to a $125 \times$ $85-\mathrm{mm}^{2}$ plane ITO/glass electrode with silicon bonding. The large plane ITO/glass electrode was placed on the bottom of the large electrode chamber device and housed in a sterile square plastic dish. Thirty-millimeter-diameter sections of the Pt ring counter electrode and $\mathrm{Ag} / \mathrm{AgCl}$ reference electrode were placed on the plastic lid of the square plastic dish.

Both the patterned and the large ITO/glass electrodes were sonicated in ultrapure water for $5 \mathrm{~min}$ and immersed in $1 \mathrm{M} \mathrm{NaOH}$ for $5 \mathrm{~min}$ to remove any unwanted deposits. After the procedure, the electrodes were washed with ultrapure water and dried. Then, the three electrode chambers were irradiated with UV light for $5 \mathrm{~min}$ for sterilization.
Potential Application Constant and triangular potentials were applied to the working ITO/glass electrode using the $\mathrm{Ag} / \mathrm{AgCl}$ reference and the Pt counter electrode (Fig. 1). The constant potential application was done using a potentiostat (PS-14, Toho Technical Research, Tokyo, Japan). For 9MHz triangular wave potential application (Koyama 2011), a coaxial cable was rolled up three times and made to a $10-\mathrm{cm}-$ diameter coil. The coaxial cable coil connected between a function generator (AD-8624A, A\&D Company, Tokyo, Japan) and the potentiostat (Toho Technical Research). The output potentials were checked by a digital oscilloscope (MT770, Xiamen Lilliput technology Co., Ltd., Fujian, China). The function generator generated $0 \sim \pm 1.0 \mathrm{~V} 3-\mathrm{MHz}$ rectangular wave signals linearly changed to $0 \sim \pm 10-\mathrm{mV}$ vs. $\mathrm{Ag} / \mathrm{AgCl}$ 9-MHz triangular wave potentials by impedance of both the coiled coaxial cable and the potentiostat. The function generator generated $\pm 4.0 \mathrm{~V} 3$-MHz rectangular wave signal which was necessary to obtain \pm 20 -mV vs. $\mathrm{Ag} / \mathrm{AgCl} 9$ - $\mathrm{MHz}$ triangular wave potential. The $9-\mathrm{MHz}$ triangular wave potential was used for microbial detachment experiments.

For attachment of the microorganisms to the patterned ITO/glass electrode regions (Fig. 1), a constant potential was applied to the electrode for $24 \mathrm{~h}$. The cultured 
microorganisms and soil or sediment samples were suspended in either Dulbecco's PBS(-) (Wako, Osaka, Japan) , MOPS buffer (10 g/L; pH 7.0, Dojindo, Kumamoto, Japan) , tricine buffer (10 g/L; pH7.0, Dojindo), $280 \mathrm{mM}$ glucose solution $(10 \mathrm{~g} / \mathrm{L}), \mathrm{LB}$ medium, or artificial seawater $(30 \mathrm{~g}$ of $\mathrm{NaCl}, 0.7 \mathrm{~g}$ of $\mathrm{KCl}, 5.3 \mathrm{~g}$ of $\mathrm{MgSO}_{4} \cdot 7 \mathrm{H}_{2} \mathrm{O}, 10.8 \mathrm{~g}$ of $\mathrm{MgCl}_{2} \cdot 6 \mathrm{H}_{2} \mathrm{O}, 1 \mathrm{~g}$ of $\mathrm{CaCl}_{2} \cdot 2 \mathrm{H}_{2} \mathrm{O}$ per liter). Each of the test microorganisms was allowed to grow overnight, then centrifuged for $2 \mathrm{~min}$ at $2,150 \times g$ and $4{ }^{\circ} \mathrm{C}$, and replaced in the selected solution at each cultivation temperature. In the electrical attachment experiments with dead E. coli, the pellet was resuspended in $70 \% \mathrm{EtOH}$ with vortexing and incubated for $1 \mathrm{~h}$ at $60{ }^{\circ} \mathrm{C}$. After $70 \% \mathrm{EtOH}$ fixation, the $E$. coli cells were centrifuged for $2 \mathrm{~min}$ at $2,150 \times g$ and $4{ }^{\circ} \mathrm{C}$ and then replaced in PBS(-). The microorganism suspensions were diluted to a concentration of $1 \times 10^{6}$ cells $/ 5 \mathrm{ml}$ and poured into the three-electrode chamber system (Fig. 1). In the experiments with sediment and soil samples, $0.1 \mathrm{~g} / \mathrm{ml}$ of the garden soil in the selected solution at room temperature (RT) or $0.1 \mathrm{~g} / \mathrm{ml}$ of the deep-sea sediment in artificial seawater at $4{ }^{\circ} \mathrm{C}$ was suspended with 5 -min vortexing. The suspended soil or sediment samples were diluted to a concentration of $50 \mu \mathrm{g} / 5 \mathrm{ml}$ in the selected solution and then poured into the chamber system. To detach the microorganisms from the electrode surface, $\pm 10-\mathrm{mV}$ vs. $\mathrm{Ag} / \mathrm{AgCl} 9$ $\mathrm{MHz}$ triangular wave potential was applied to the electrode in either PBS(-) at RT or artificial seawater at $4{ }^{\circ} \mathrm{C}$ for $60 \mathrm{~min}$. Under anaerobic experimental conditions, the electrical attachment of microorganisms was performed using an anaerobic cultivation system (Anaero pack A-07 with anaerobic jar, Mitsubishi Gas Chemical Company, Inc., Tokyo, Japan). A hole was drilled through the lid of the anaerobic jar to allow three conductive wires to penetrate, and the hole was then blocked with epoxy resin bonding. The three-electrode chamber system connected to the conductive wires through the lid was housed in the anaerobic cultivation system.

For phylogenetic analyses of microorganisms in soil or sediment samples, microorganisms were collected from the sample using the large electrode chamber device. The microorganisms collected were purified twice using an electrical retrieval method. One gram per milliliter of the soil or the sediment in either PBS(-) at RT or artificial seawater at $4{ }^{\circ} \mathrm{C}$ was treated with 5 -min vortexing. To attach the microorganisms in the soil or sediment sample to the large ITO/glass electrode, $12.5 \mathrm{ml}$ of the suspended sample in either PBS(-) at RT or artificial seawater at $4{ }^{\circ} \mathrm{C}$ was poured into the large chamber. In the deep-sea sediment sample, a $-0.3 \mathrm{~V}$ vs. $\mathrm{Ag} / \mathrm{AgCl}$ constant potential was applied to the large electrode for $2 \mathrm{~h}$ at $4{ }^{\circ} \mathrm{C}$ in artificial seawater. In the garden soil sample, $-0.4 \mathrm{~V}$ vs. $\mathrm{Ag} / \mathrm{AgCl}$ constant potential was applied to the large electrode for $2 \mathrm{~h}$ at RT in PBS(-). After $2 \mathrm{~h}$ of application, the electrode was washed three times with either artificial seawater at $4{ }^{\circ} \mathrm{C}$ or
PBS(-) at RT, and the microorganisms attached to the electrode were detached by applying $\pm 10-\mathrm{mV}$ vs. $\mathrm{Ag} / \mathrm{AgCl} 9-\mathrm{MHz}$ triangular wave potential for $30 \mathrm{~min}$ in $12.5 \mathrm{ml}$ of either fresh artificial seawater at $4{ }^{\circ} \mathrm{C}$ or fresh $\mathrm{PBS}(-)$ at RT. After the triangular wave potential application, the detached microorganisms were collected with a cell scraper and transferred to a new large electrode chamber device, and $-0.3 \mathrm{~V}$ or $-0.4 \mathrm{~V}$ vs. $\mathrm{Ag} / \mathrm{AgCl}$ constant potential was applied for a further $2 \mathrm{~h}$ at $4{ }^{\circ} \mathrm{C}$ in seawater or at RT in PBS(-). After application, the electrode was washed three times, and the microorganisms on the electrode were detached by application of $\pm 10-\mathrm{mV}$ vs. $\mathrm{Ag} / \mathrm{AgCl} 9-\mathrm{MHz}$ triangular wave potential for a further $30 \mathrm{~min}$ in $12.5 \mathrm{ml}$ of either fresh artificial seawater at $4{ }^{\circ} \mathrm{C}$ or fresh PBS(-) at RT. After these procedures, the electrically collected microorganisms were used in phylogenic analyses.

We observed a weak electrical current of -0.19 to $-0.27 \mu \mathrm{A} / \mathrm{cm}^{2}$ when a negative constant potential between -0.3 - and $-0.4 \mathrm{~V}$ vs. $\mathrm{Ag} / \mathrm{AgCl}$ was applied to the samples except when using $0.1 \mathrm{~g} / \mathrm{ml}$ of sediment or soil suspension. We measured -0.79 to $-0.88 \mu \mathrm{A} / \mathrm{cm}^{2}$ of the weak current using $0.1 \mathrm{~g} / \mathrm{ml}$ of the sediment or soil suspension.

Optical Microscopic Observation of Dehydrogenase-Active Microorganisms To analyze the respiratory activity of the microorganisms attached to the electrode, we used a Bacstain CTC rapid staining kit for microscopy (Dojindo, Kumamoto, Japan). The respiratory activity staining solution was comprised of $20 \mu \mathrm{l}$ of $50 \mathrm{mM} \mathrm{CTC}$ solution and $5 \mu \mathrm{l}$ of enhancing reagent $\mathrm{B}$ added to $1 \mathrm{ml}$ of either $\mathrm{PBS}(-)$ or artificial seawater. After vortexing the staining solution, the microorganisms on the electrode were incubated with the staining solution at cultivation temperature for $30 \mathrm{~min}$ and observed using the confocal laser scanning microscope system (FV500, Olympus, Tokyo, Japan).

Analyses of Detachment, Survival, and Viable Bacteria Collection Rates For measurement of detachment rates, cell numbers were counted at randomly selected $50 \times 50-\mu \mathrm{m}^{2}$ regions on the ITO electrode before and after triangular wave potential application. The detachment rate was calculated from the cell number after the triangular wave potential application divided by the cell number before the electrical application.

For measurement of survival rates, more than 300 of total microorganisms on the electrodes were distinguished using a live/dead backlight bacterial viability kit for microscopy and quantitative assays (L7012, Molecular Probes, Eugene, OR, USA) using the confocal laser scanning microscope system (FV500, Olympus) according to the manufacturer's recommendations. The survival rates were calculated from the sum of three independent experiments.

In cell counts of microorganisms in soil, the suspended soil samples diluted to a concentration of $50 \mu \mathrm{g} / 5 \mathrm{ml}$ in the selected solution were treated with the live/dead backlight 
bacterial viability kit for microscopy and quantitative assays. Then, the microorganisms in soil were counted with a hemacytometer under confocal laser scanning microscopic observation before and after high-frequency triangular wave potential application.

In the viable bacteria collection rate analyses of $B$. subtilis and $E$. coli, we collected the supernatants after the $-0.4 \mathrm{~V}$ vs. $\mathrm{Ag} / \mathrm{AgCl}$ potential and after the triangular wave potential applications. Colonies were formed on LB agar plates at $37^{\circ} \mathrm{C}$. The viable bacteria collection rate was calculated from the colony number after the triangular wave potential application divided by the total colony number. Data were obtained from the sum of two or three independent experiments.

Atomic Force Microscopic Observation E. coli attached to the microelectrode (Fig. 1) was fixed with $2.5 \%$ glutaraldehyde (Sigma, St. Louis, MO, USA) in PBS(-) for $1 \mathrm{~h}$ at RT, rinsed with milliQ water (Millipore, Billerica, MA, USA), dried in a desiccator, and observed with an atomic force microscope (MFP-3D-Bio, Asylum Research, Santa Barbara, CA, USA) using the acoustic AC mode with a microcantilever (OMCL-AC240TS-C2, Olympus). All images were obtained with 256 scan points, 256 scan lines, and a scan rate of $0.36 \mathrm{~Hz}$ under atmospheric pressure at RT. Images were analyzed using MFP3D software (Asylum Research) and argyle light software (Asylum Research).

Scanning Electron Microscopic Observation Microorganisms attached to the patterned ITO/glass electrode were prefixed with $2.5 \%$ glutaraldehyde in $\mathrm{PBS}(-)$ for $1 \mathrm{~h}$ at each cultivation temperature. For observations of $S$. violacea, conductive staining procedures were performed with artificial seawater instead of PBS(-). After washing with PBS(-) three times for $10 \mathrm{~min}$ each, the microorganisms were postfixed with $2 \%$ osmium tetraoxide in $\operatorname{PBS}(-)$ for $2 \mathrm{~h}$ at $4{ }^{\circ} \mathrm{C}$. After washing with distilled water at $4{ }^{\circ} \mathrm{C}$ six times for $10 \mathrm{~min}$ each, conductive staining was performed by incubating with $0.2 \%$ aqueous tannic acid (pH6.8) at $4{ }^{\circ} \mathrm{C}$ for $30 \mathrm{~min}$. The microorganisms were washed with distilled water at $4{ }^{\circ} \mathrm{C}$ six times for $10 \mathrm{~min}$ each and then treated with $1 \%$ aqueous tannic acid at $4{ }^{\circ} \mathrm{C}$ for $30 \mathrm{~min}$. After washing with distilled water at $4{ }^{\circ} \mathrm{C}$ six times for $10 \mathrm{~min}$ each, the microorganisms were dehydrated in a graded ethanol series and critical point-dried (JCPD-5 critical point drier, Japan Electron Optics Laboratories Ltd., Tokyo, Japan). The microorganisms on the electrode were coated with osmium using an osmium plasma coater (POC-3, Meiwa Shoji Co., Osaka, Japan) and observed with a field emission scanning electron microscope (JSM-6700 F, Japan Electron Optics Laboratories Ltd.) at an acceleration voltage of $5 \mathrm{kV}$.

DNA Extraction, Small Subunit rRNA Gene PCR Amplification, and Phylogenetic Analyses Environmental genomic DNA from the deep-sea sediments was extracted using Isoil Large for Beads ver. 2 (Nippon Gene Corp., Toyama, Japan) with slight modifications $(100 \mu \mathrm{g} / \mathrm{ml}$ lysozyme was added to the lysis solution and incubated for $60 \mathrm{~min}$ ). DNA marker used an all purpose Hi-Lo DNA marker (Bionexus, Inc., Oakland, CA, USA). Genomic DNA of the electrically isolated microorganisms in the deep-sea sediment was extracted using the CTAB method. The nearly whole-length bacterial small subunit SSU rRNA gene fragments were amplified from the environmental genomic DNA with general primers $27 \mathrm{~F}$ (5'-AGAGTTTGATCMTGGCTCAG-3') and 1492R (5'-GGCTACCTTGTTACGACTT-3') (Lane et al. 1985). Each 25- $\mu$ l aliquot of the reaction mixture contained $2.5 \mu \mathrm{l}$ of $10 \times$ PCR buffer (Takara Bio Inc., Otsu, Japan), $4 \mu$ l of dNTP mix (2.5 nM each), $1 \mu$ l of $27 \mathrm{~F}$ primer $(10 \mu \mathrm{M}), 1 \mu \mathrm{l}$ of $1492 \mathrm{R}$ primer $(10 \mu \mathrm{M}), 2.5 \mu \mathrm{l}$ of $\mathrm{MgCl}_{2}$ solution $(25 \mathrm{mM}), 0.25 \mu \mathrm{l}$ of LA Taq polymerase, $1 \mu \mathrm{l}$ of template DNA, and RNase/DNase-free water to a final volume of $25 \mu \mathrm{l}$. The following PCR program was used: $96^{\circ} \mathrm{C}$ for $5 \mathrm{~min}$, followed by 25 cycles of $96^{\circ} \mathrm{C}$ for $20 \mathrm{~s} ; 55^{\circ} \mathrm{C}$ for $15 \mathrm{~s}$; and $72{ }^{\circ} \mathrm{C}$ for $90 \mathrm{~s}$, followed by $72{ }^{\circ} \mathrm{C}$ for $7 \mathrm{~min}$. The products were checked by electrophoresis, purified using QIAquickGel Extraction Kit (Qiagen, Valencia, CA, USA), and subsequently cloned into a pT7Blue-2 (Merck Chemicals, Darmstadt, Germany) vector using Competent High DH5 $\alpha$ (Toyobo, Osaka, Japan) as the host. Approximately 130 clones of each library containing the fragments of expected length were selected randomly and sequenced using a BigDye Terminator v3.1 Cycle Sequencing Kit (Life Technologies Corp., Carlsbad, CA, USA) in a 3730xl DNA analyzer following the manufacturer's recommendations. Sequences representing different phylotypes were deposited in the GenBank database with accession numbers AB687722-AB687989.

Sequences were checked with both Mallard software (Ashelford et al. 2006) and the CHECK_CHIMERA tools from the Ribosomal Database Project II (http://rdp8.cme. msu.edu/cgis/chimera.cgi? su $=\mathrm{SSU}$ ), and chimeric sequences were excluded from further analyses. The closest relatives of the remaining sequences were obtained from the SILVA database (http://www.arb-silva.de/) using the BLAST program.

Statistical Analysis Statistical analysis was performed using Student's $t$-test. The calculations were performed using Microsoft Excel.

\section{Results}

Electrical Attachment of Escherichia coli to a Patterned ITO Electrode

To examine whether the microorganisms were attracted by and attached to a reticulated ITO/glass electrode region with an applied potential (Fig. 1), the gram-negative bacterium $E$. 
coli was used as a test microorganism. Cultured E. coli were washed with $\operatorname{PBS}(-)$ and diluted to a concentration of $1 \times$ $10^{6}$ cells $/ 5 \mathrm{ml}$ in $\mathrm{PBS}(-)$ at $\mathrm{RT}$ and then poured into the three-electrode chambers on a glass slide (Fig. 1). To analyze the respiratory activity of the microorganisms attached to the electrode, we used a Bacstain CTC rapid staining kit for microscopy. Cyano-ditolyl-tetrazolium chloride (CTC), a monotetrazolium redox dye that produces red fluorescent formazan when it is chemically or biologically reduced as in the presence of dehydrogenase activity, was used as an indicator of respiration (Frederiks et al. 2006; Hiraishi and Yoshida 2004). Confocal laser scanning microscopy showed that the fluorescent formazan was exclusively localized at the surface of individual cells and not at intracellular sites (Frederiks et al. 2006). Figure 2a shows the distribution pattern of $E$. coli on the patterned ITO electrode after $24 \mathrm{~h}$ of constant potential applications. A constant potential between +0.6 and $-0.6 \mathrm{~V}$ vs. $\mathrm{Ag} / \mathrm{AgCl}$ was applied to the patterned ITO electrode in PBS(-) for $24 \mathrm{~h}$ at RT. After the potential applications, living $E$. coli on the electrode was stained with CTC to determine respiratory activity, and red fluorescent formazan production was observed using the confocal laser scanning microscope. Living E. coli was attracted by and selectively attached to the reticulated ITO electrode surface to which a negative potential between -0.3 and $-0.5 \mathrm{~V}$ vs. $\mathrm{Ag} / \mathrm{AgCl}$ was applied (Fig. 2a). A $-0.4 \mathrm{~V}$ vs. $\mathrm{Ag} / \mathrm{AgCl}$ constant potential application induced the maximum attachment of living $E$. coli to the reticulated ITO electrode region (Fig. 2a). Although most microorganisms including $E$. coli strains have a negative zeta potential under neutral pH (Bayer and Sloyer 1990; Ebersole and McCormick 1993), few or no E. coli cells selectively attached to the ITO electrode region to which the positive potential was applied (Fig. 2a). In addition, we investigated whether dead E. coli cells selectively attached to the ITO electrode region to which a negative potential was applied. The cultured $E$. coli cells were treated with $70 \% \mathrm{EtOH}$ for $1 \mathrm{~h}$ at $60^{\circ} \mathrm{C}$ and replaced in $\mathrm{PBS}(-)$ at RT. After fixation of the $E$. coli cells, $-0.4 \mathrm{~V}$ vs. $\mathrm{Ag} / \mathrm{AgCl}$ constant potential was applied to the patterned ITO electrode for $24 \mathrm{~h}$ at RT (Fig. 2b). Few or no dead E. coli cells were observed on the ITO electrode region to which the $-0.4 \mathrm{~V}$ vs. $\mathrm{Ag} / \mathrm{AgCl}$ potential was applied (Fig. 2b). To clarify the interaction between living $E$. coli and the negative applied potential electrode, we examined whether the $E$. coli cells in glucose or PBS(-) solutions and under aerobic or anaerobic conditions were attracted by and attached to the negative-potential electrode (Fig. 2b, c). E. coli cells suspended in either a
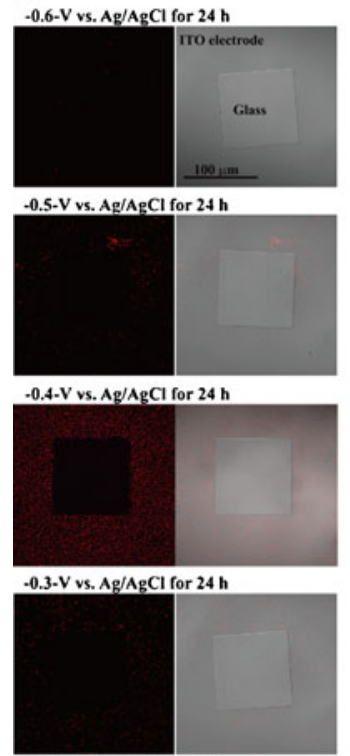

$-0.2-\mathrm{V} v s . \mathrm{Ag} / \mathrm{AgCl}$ for $24 \mathrm{~h}$

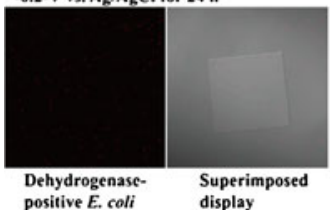

Fig. 2 Attachment of $E$. coli cells to the constant potential applied electrode. a Distribution patterns of $E$. coli cells on the constant potential applied patterned ITO electrodes in PBS(-) for $24 \mathrm{~h}$ at RT. $E$. coli cells were stained with a Bacstain CTC rapid staining kit. b Distribution b
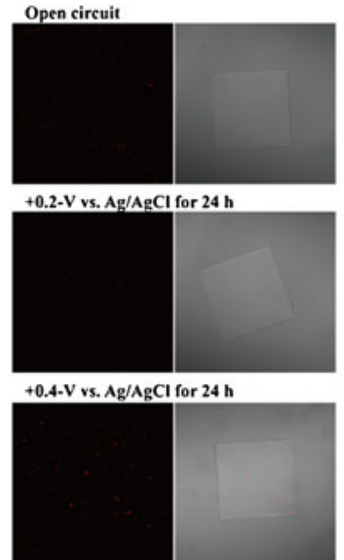

$+0.6-\mathrm{V} \mathrm{vs} . \mathrm{Ag} / \mathrm{AgCl}$ for $24 \mathrm{~h}$

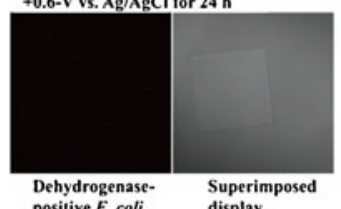

$\begin{array}{ll}\begin{array}{l}\text { Dehydrogenase- } \\ \text { positive } E \text {. coli }\end{array} & \begin{array}{l}\text { Superim } \\ \text { display }\end{array}\end{array}$

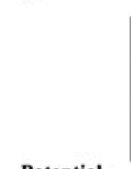

Solution

Aerobic/ Anaerobic

C

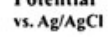

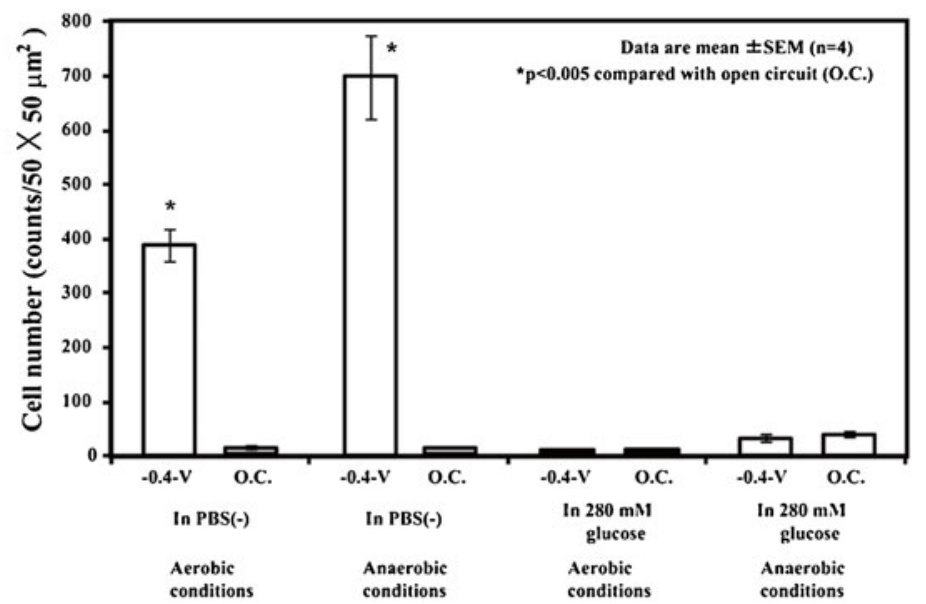

pattern and $\mathbf{c}$ cell density of $E$. coli on the patterned ITO electrode surface. E. coli cells pretreated with $70 \% \mathrm{EtOH}$ were stained with SYTO9. A $-0.4 \mathrm{~V}$ vs. $\mathrm{Ag} / \mathrm{AgCl}$ electrode was applied for $24 \mathrm{~h}$ in PBS(-) or $280 \mathrm{mM}$ glucose under aerobic or anaerobic conditions at RT 
$280 \mathrm{mM}$ glucose solution or PBS(-) were poured into the three-electrode chamber system. $\mathrm{A}-0.4 \mathrm{~V}$ vs. $\mathrm{Ag} / \mathrm{AgCl}$ potential was applied to the $E$. coli cells under either aerobic or anaerobic conditions for $24 \mathrm{~h}$ at RT. Figure $2 \mathrm{~b}$, c shows the density of the $E$. coli cells attached to the electrode surface. In PBS(-) conditions, $-0.4 \mathrm{~V}$ vs. $\mathrm{Ag} / \mathrm{AgCl}$ potential application enhanced the $E$. coli cell density on the reticulated ITO electrode region compared with the open circuit (Fig. 2b, c). The attached E. coli cell density was increased by 46- and 68-fold compared with the open circuit under aerobic and anaerobic conditions, respectively (Fig. 2b, c). In contrast to the enhanced E. coli cell density in $\operatorname{PBS}(-)$, no statistically significant differences between the $-0.4 \mathrm{~V}$ vs. $\mathrm{Ag} / \mathrm{AgCl}$ potential application and the open
Fig. 3 Fibrous elongated materials of $E$. coli cells attached to patterned ITO electrodes. a $E$. coli cells attached to 5- $\mu \mathrm{m}$-diameter circular microelectrodes to which $-0.4 \mathrm{~V}$ vs. $\mathrm{Ag} / \mathrm{AgCl}$ potential was applied in $\mathrm{PBS}(-)$ for $15 \mathrm{~h}$ at RT. b E. coli cells attached to the JAMSTEC microelectrode to which $-0.4 \mathrm{~V}$ vs. $\mathrm{Ag} / \mathrm{AgCl}$ potential was applied in PBS(-) for $24 \mathrm{~h}$ at RT. Magnified AFM image is the middle region of "C." c AFM images of E. coli cells attached to the JAMSTEC microelectrode. Arrows indicate elongated fibrous materials. d SEM images of E. coli cells attached to the reticulated ITO electrode a

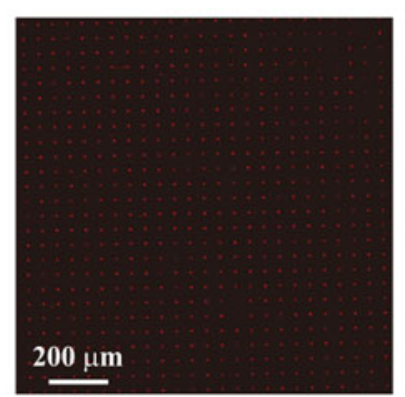

Dehydrogenase-positive microorganisms

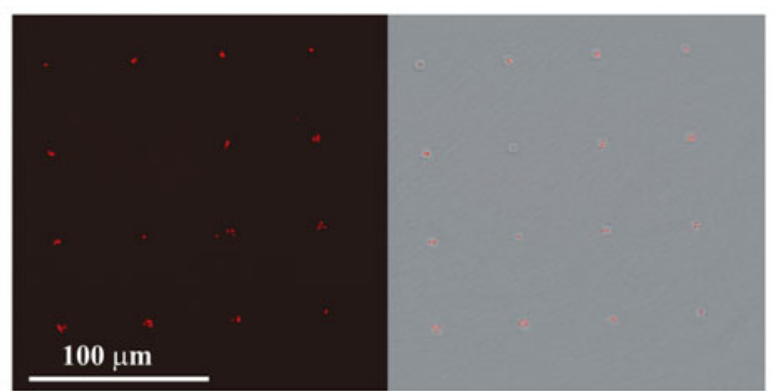

Superimposed display

Dehydrogenase-positive microorganisms

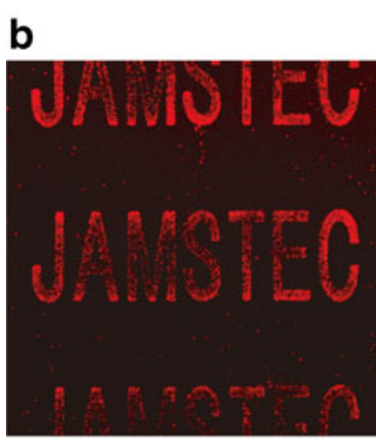

Dehydrogenase-positive microorganisms

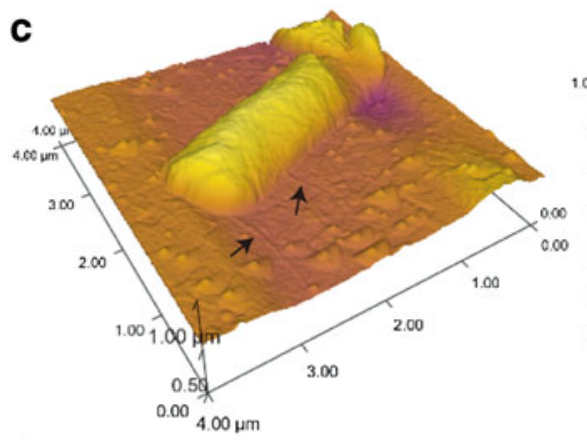

d

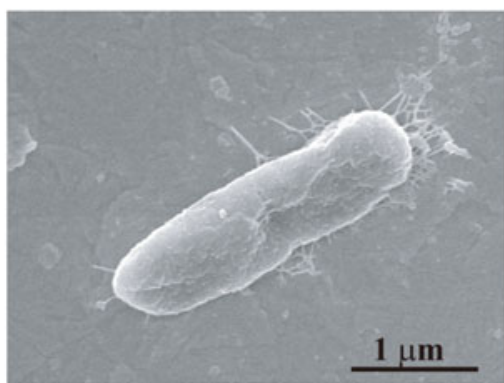

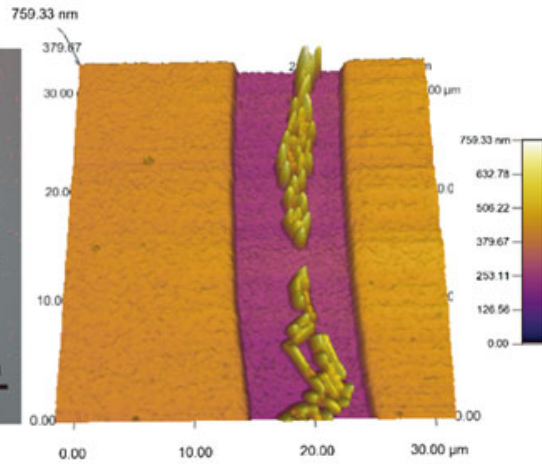

Superimposed display

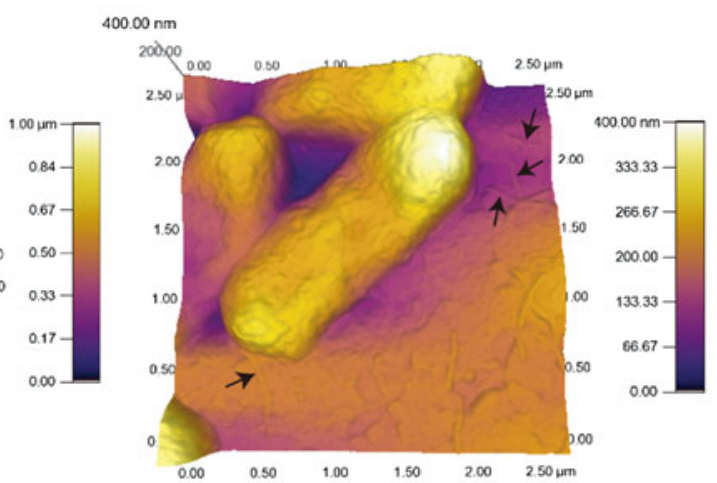

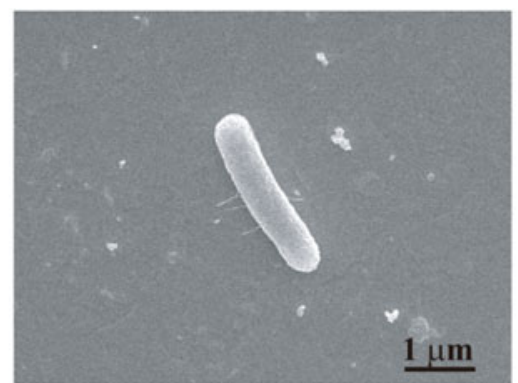


circuit were observed in $280 \mathrm{mM}$ glucose under aerobic or anaerobic conditions (Fig. 2b, c). Figure 2 indicates that the principle of electrophoresis does not explain the phenomena of the negative potential-induced selective attachment of living $E$. coli to the reticulated ITO electrode region.

To perform accurate cell arrangement on the electrode surface, we examined whether $E$. coli cells recognized small regions of the negative applied potential microelectrode (Figs. 1 and 3a, b). Figure 3a, b shows living E. coli cells attached to small regions of the patterned ITO electrode to which $-0.4 \mathrm{~V}$ vs. $\mathrm{Ag} / \mathrm{AgCl}$ potential was applied at $\mathrm{RT}$ in PBS(-). We confirmed that a small number of $E$. coli cells selectively attached to the negative-potential 5 - $\mu$ m-diameter circular microelectrode array even if the electrode surface area was small compared with the reticulated electrode (Figs. 1 and $3 \mathrm{a}$ ). Few or no E. coli cells were attached to the $\mathrm{SiO}_{2}$ coating region of the microelectrode array (Figs. 1 and 3a). The results in Fig. 3a clearly show that electrical modulation of the spatial configuration of $E$. coli cells was successful using the patterned ITO electrode culture system. To investigate how E. coli cells attached to the negative applied potential ITO electrode region, we observed the cells on the patterned electrode using a confocal laser scanning microscope, an atomic force microscope (AFM), and a scanning electron microscope (SEM) (Figs. 1 and 3). Figure 3b, c shows optical microscopic and AFM images of the $E$. coli cells attached to the electrode regions. The $E$. coli cells that attached to the electrode surface (Fig. 3c) had an elongated, short fibrous shape. We further examined the $E$. coli cells attached to the electrode surface using SEM (Fig. 3d). Figure 3d shows SEM images of E. coli cells on the negative applied potential electrode surface. E. coli cells appeared to adhere to the negative potential electrode surface with some elongated, short fibrous materials (Fig. 3c, d). a
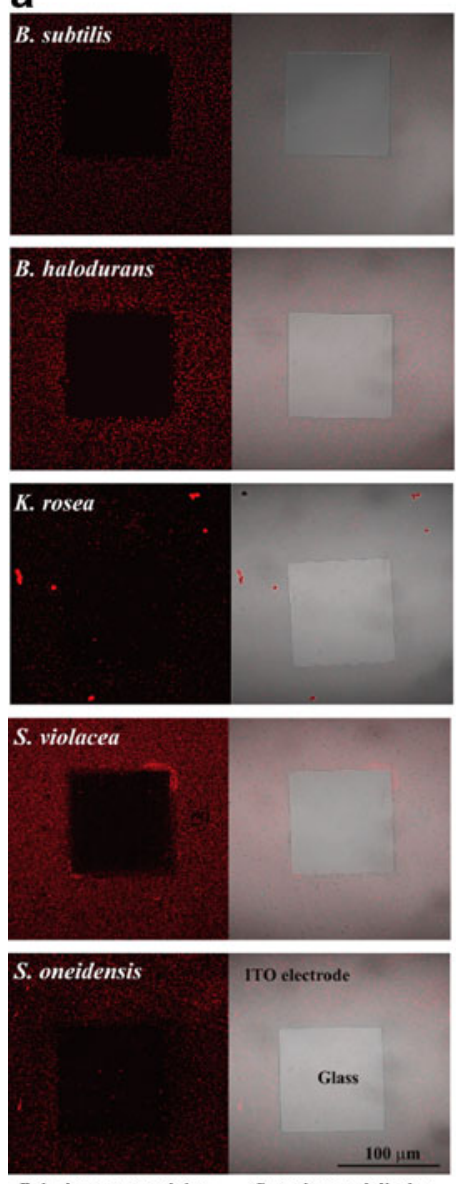

Dehydrogenase staining

Superimposed display
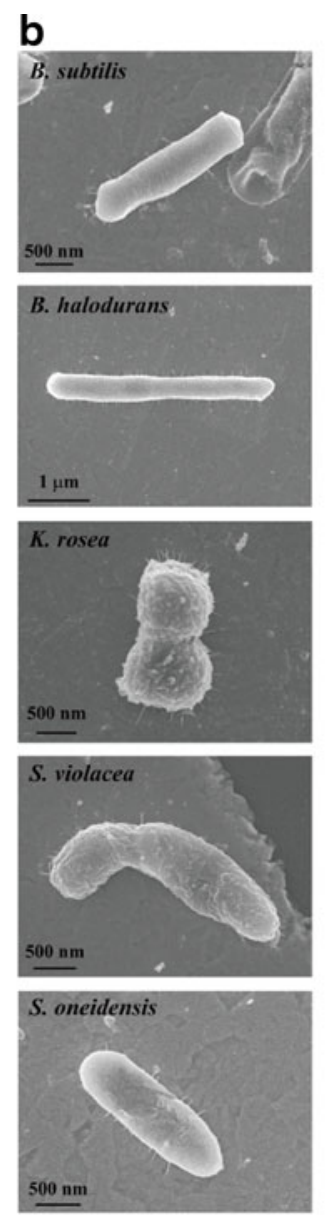

Fig. 4 A negative potential attracted cultured and soil microorganisms to the patterned ITO electrode. a B. halodurans, B. subtilis, S. oneidensis, and $K$. rosea attached to the patterned ITO electrode to which $-0.4 \mathrm{~V}$ vs. $\mathrm{Ag} / \mathrm{AgCl}$ potential was applied for $24 \mathrm{~h}$ in $\mathrm{PBS}(-)$ at RT. $S$. violacea attached to the patterned ITO electrode to which $-0.3 \mathrm{~V}$ vs. $\mathrm{Ag} / \mathrm{AgCl}$ potential was applied for $24 \mathrm{~h}$ in artificial seawater at $8{ }^{\circ} \mathrm{C}$. b
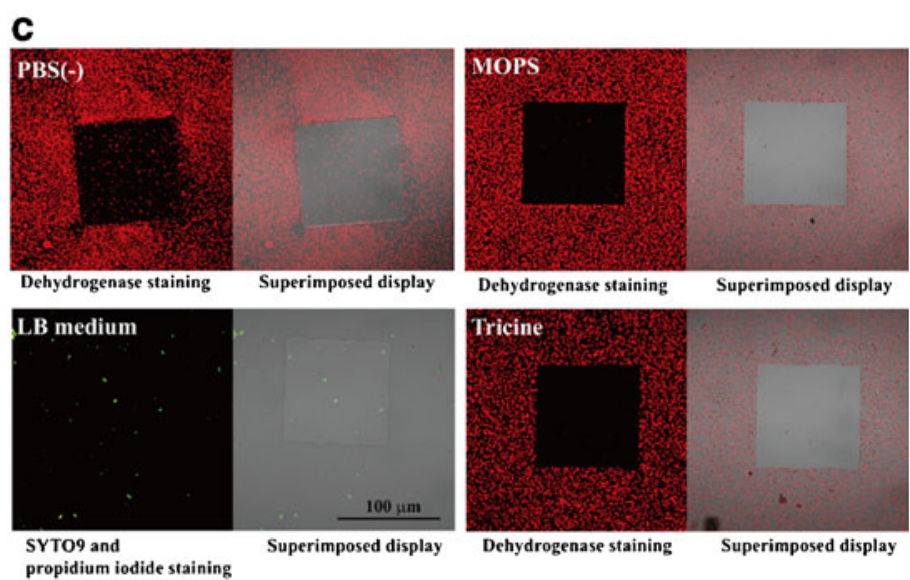

propidium iodide staining

d

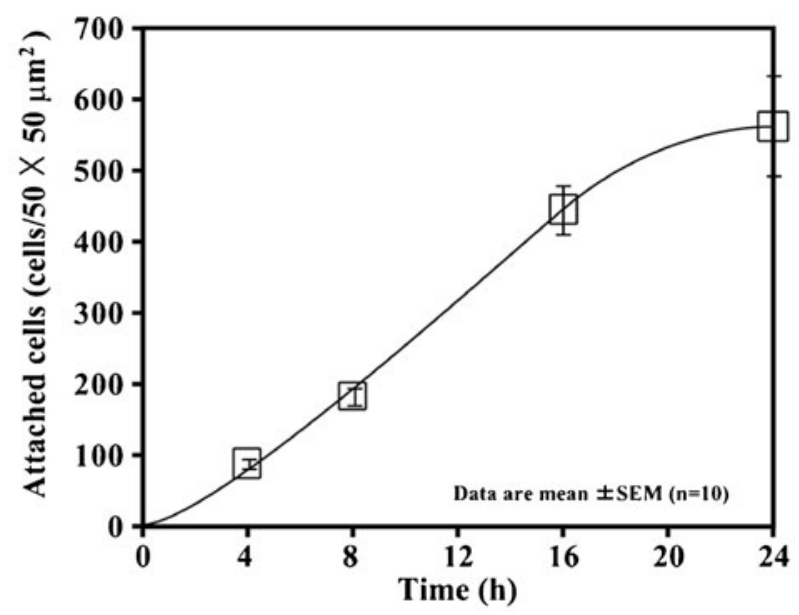

SEM images of five different microorganisms attached to the patterned ITO electrode. c Distribution pattern of garden soil microorganisms on the patterned ITO electrode after $24 \mathrm{~h}$ of potential application in four different solutions. A $-0.4 \mathrm{~V}$ vs. $\mathrm{Ag} / \mathrm{AgCl}$ constant potential was applied at RT. d Time course of soil microorganism attachment to the electrode with $-0.4 \mathrm{~V}$ applied potential in $\operatorname{PBS}(-)$ at RT 
Electrical Attachment of B. subtilis, B. halodurans, $K$. rosea, $S$. violacea, $S$. oneidensis, and Soil Microorganisms to the Patterned ITO Electrode

We investigated whether a negative applied potential induced not only $E$. coli but also other microorganisms to attach to the reticulated ITO electrode. As test cells, we used one typical gram-positive bacterium, B. subtilis; two environmental bacteria, B. halodurans and $S$. oneidensis; one actinomycete, $K$. rosea; and one deep-sea bacterium, $S$. violacea. Figure $4 \mathrm{a}$ shows the distribution pattern of $B$. subtilis, B. halodurans, K. rosea, S. violacea, and S. oneidensis on the patterned ITO electrode after $24 \mathrm{~h}$ of constant potential application. They were attracted by and selectively attached to the reticulated ITO electrode surface to which a negative potential was applied (Fig. 4a). Except for $S$. violacea, $-0.4 \mathrm{~V}$ vs. $\mathrm{Ag} / \mathrm{AgCl}$ potential induced the maximum attachment of these organisms to the reticulated ITO electrode region (Fig. $4 \mathrm{a}$ ). $\mathrm{A}-0.4 \mathrm{~V}$ vs. $\mathrm{Ag} / \mathrm{AgCl}$ or lower applied potential in artificial seawater induced an adsorption wave of positive ions to the electrode surface, and the maximum attachment of $S$. violacea occurred a $-0.3 \mathrm{~V}$ vs. $\mathrm{Ag} / \mathrm{AgCl}$ applied potential (Figs. $4 \mathrm{a}$ and 5). Figure $4 \mathrm{~b}$ shows SEM images of B. subtilis, B. halodurans, K. rosea, $S$. violacea, and $S$. oneidensis on the reticulated ITO electrode region. All five microorganisms also produced short fibrous materials that were very similar in both form and size to those of E. coli and attached to the negative applied potential electrode region (Figs. 3d and 4b).

Next, we examined whether microorganisms in soil were attracted by the negative applied potential electrode in various types of solution (Figs. 4c and 5). Garden soil samples
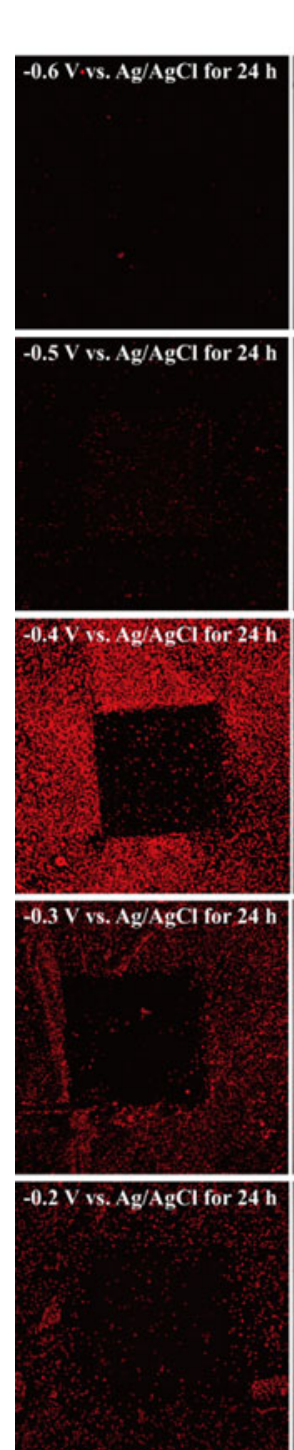

Dehydrogenasepositive microorganisms
Garden soil in PBS(-)
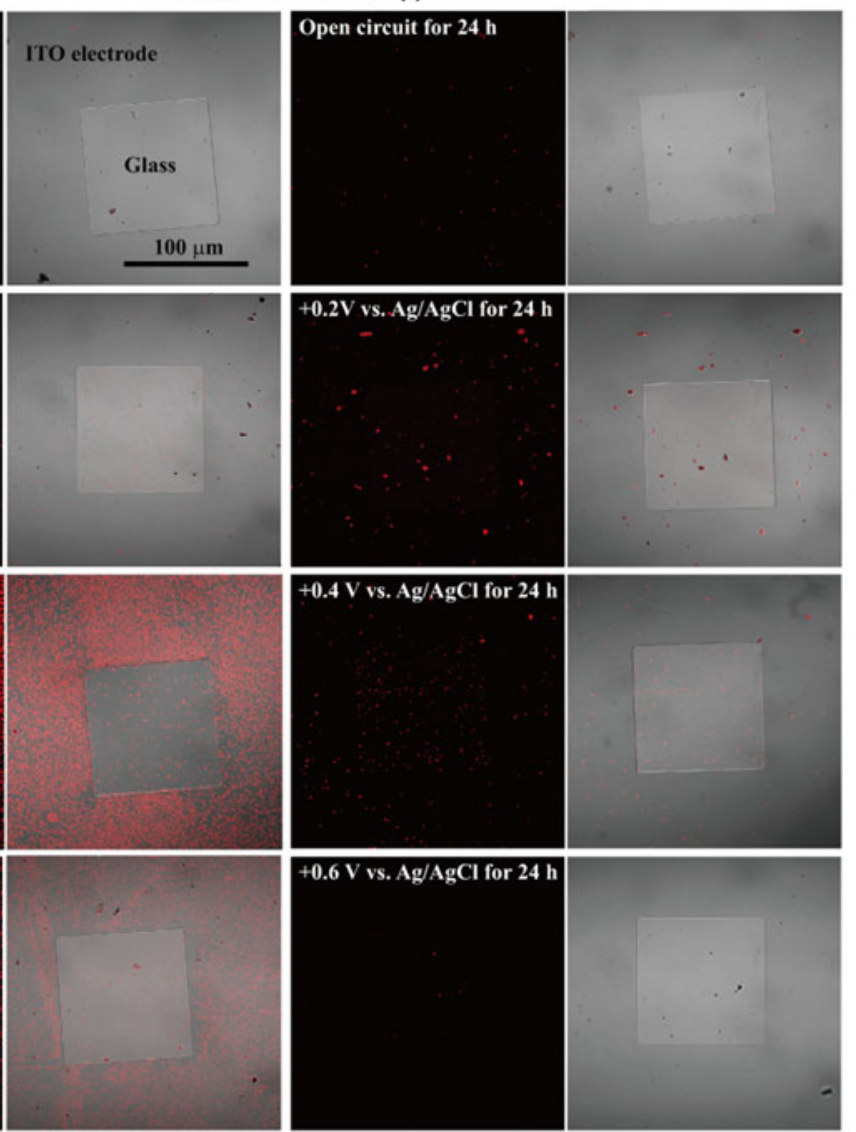

Dehydrogenasepositive microorganisms
Garden soil in artificial sea water
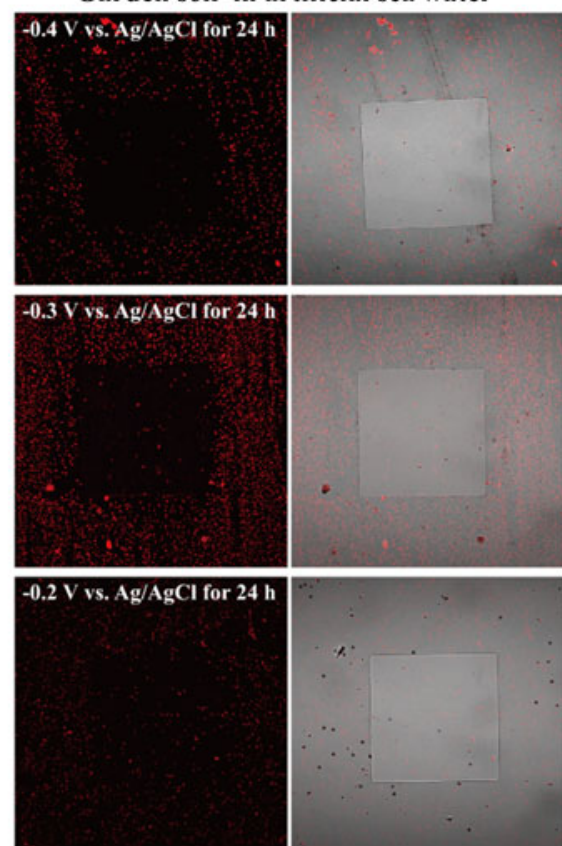

Dehydrogenasepositive microorganisms

Superimposed display

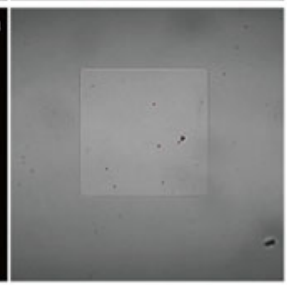

Superimposed display

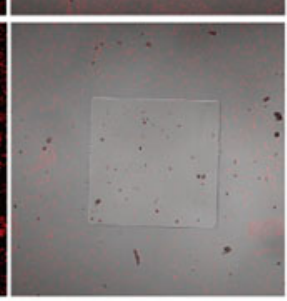

Superimposed display

Fig. 5 Distribution patterns of soil microorganisms attached to the patterned ITO electrode after $24 \mathrm{~h}$ of constant potential application at RT 
were suspended in either PBS(-), MOPS buffer, tricine buffer, or LB medium and placed in the three-electrode chamber system. A $-0.4 \mathrm{~V}$ vs. $\mathrm{Ag} / \mathrm{AgCl}$ potential was then applied to the soil samples in the various solutions for $24 \mathrm{~h}$ at RT. Figure $4 \mathrm{c}$ shows the distribution pattern of the soil microorganisms on the negative applied potential electrode surface. The soil microorganisms in each of the nonnutritive buffers such as PBS(-), MOPS buffer, and tricine buffer selectively attached to the reticulated ITO electrode region to which the $-0.4 \mathrm{~V}$ vs. $\mathrm{Ag} / \mathrm{AgCl}$ potential was applied (Fig. 4c). The characteristic features of constant potential application that induced soil microorganism attachment were nearly identical to those that induced $E$. coli attachment (Figs. 2a and 5). The soil microorganisms in PBS(-) were attracted by and selectively attached to the reticulated ITO electrode surface to which a negative potential of between -0.2 and $-0.4 \mathrm{~V}$ vs. $\mathrm{Ag} / \mathrm{AgCl}$ was applied (Fig. 5). The maximum attachment of soil microorganisms was observed at $-0.4 \mathrm{~V}$ vs. $\mathrm{Ag} / \mathrm{AgCl}$ applied potential (Fig. 5). In artificial seawater, the maximum attachment of soil microorganisms was shifted to $-0.3 \mathrm{~V}$ vs. $\mathrm{Ag} / \mathrm{AgCl}$ because the adsorption wave of positive ions occurred at $-0.4 \mathrm{~V}$ vs. $\mathrm{Ag} / \mathrm{AgCl}$ on the electrode surface (Fig. 5). Meanwhile, few soil microorganisms in LB medium attached to the ITO electrode region to which $-0.4 \mathrm{~V}$ vs. $\mathrm{Ag} / \mathrm{AgCl}$ potential was applied (Fig. 4c). When the microorganisms in LB medium were examined in the cell viability test, it was confirmed that $-0.4 \mathrm{~V}$ vs. $\mathrm{Ag} / \mathrm{AgCl}$ applied potential was nearly non-cytotoxic, and $92 \%$ (118 of 128 cells) of the soil bacteria remained alive on the electrode surface $24 \mathrm{~h}$ after the potential application (Fig. 4c). Figure $4 \mathrm{~d}$ shows the time course of garden soil microorganism attachment in PBS(-) to the reticulated ITO electrode region. The $-0.4 \mathrm{~V}$ vs. $\mathrm{Ag} / \mathrm{AgCl}$ applied potential induced microorganism attachment that increased in a linear fashion until $16 \mathrm{~h}$, after which the cell attachment rate became sluggish (Fig. 4d). The results in Figs. 2, 4, and 5 indicate that the microorganisms can attach to the electrode with a negative applied potential when the cells are suspended in non-nutritive media such as PBS(-), MOPS buffer, tricine buffer, and artificial seawater.

\section{Electrical Detachment of Microorganisms from the ITO Electrode}

After negative potential application in non-nutritive solutions for $24 \mathrm{~h}$, almost none of the soil microorganisms attached to the electrode surface could be detached by scraping several times with a rubber cell scraper. Therefore, we examined the electrical detachment and retrieval methods. In our previous study, we succeeded in detaching animal cells from an ITO electrode surface treated with extracellular matrix proteins after application of $\pm 10 \mathrm{mV}$ vs. $\mathrm{Ag} / \mathrm{AgCl} 9-\mathrm{MHz}$ triangular wave potential in $\mathrm{PBS}(-)$ for 30-60 min (Koyama 2011). Triangular wave potentialinduced animal cell detachment is almost completely noncytotoxic, and no statistically significant differences in HeLa cell growth were observed after they were subjected to trypsinization and high-frequency wave potential application (Koyama 2011). Therefore, we investigated whether high-frequency triangular wave potential application also induced the detachment of microorganisms from the ITO electrode surface. Figure 6 a shows the electrical detachment of soil microorganisms, E. coli, and B. subtilis from the

\section{a}
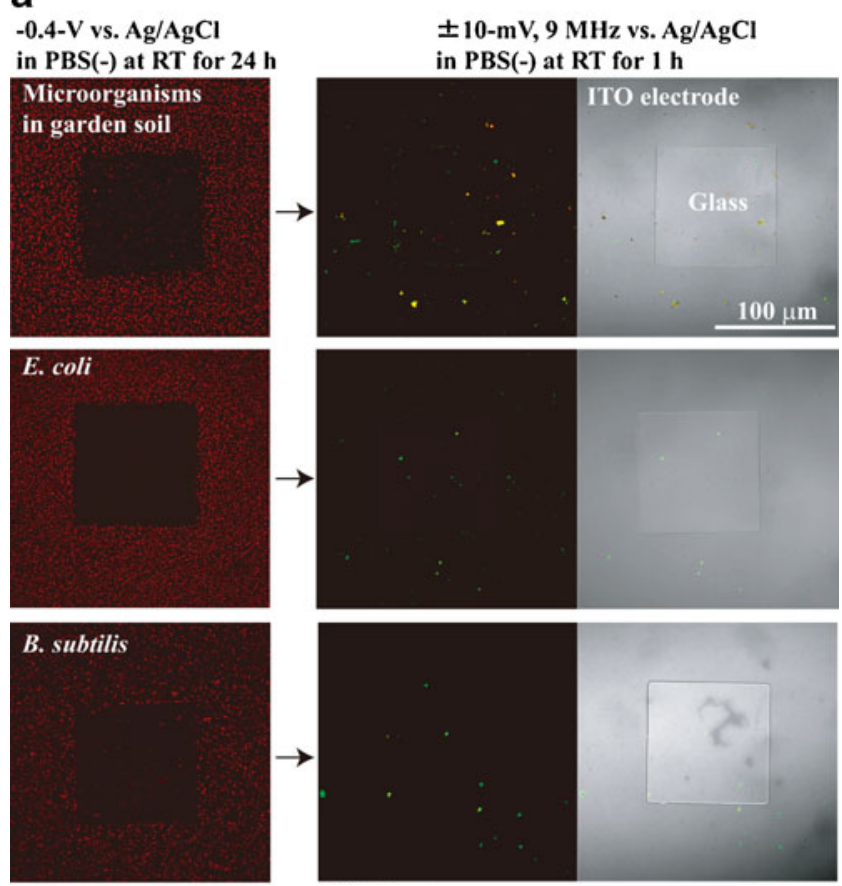

Dehydrogenase-positive microorganisms

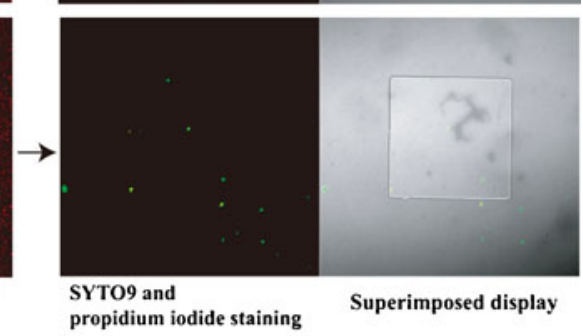

b

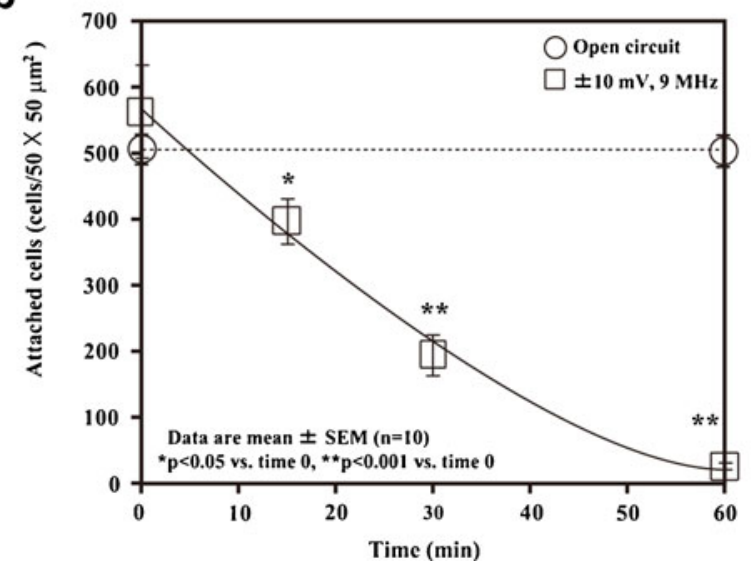

Fig. 6 Electrical detachment of microorganisms. a Photographs of electrically detached soil microorganisms, E. coli, and B. subtilis. b Time course of soil microorganism detachment from the ITO electrode. $\mathrm{A} \pm 10-\mathrm{mV}$ vs. $\mathrm{Ag} / \mathrm{AgCl} 9-\mathrm{MHz}$ triangular wave potential was applied to the electrode for $60 \mathrm{~min}$ in $\mathrm{PBS}(-)$ at $\mathrm{RT}$ 
patterned ITO electrode. After the negative potential induced microorganism attachment and the electrode surface was washed with $\mathrm{PBS}(-), \pm 10-\mathrm{mV}$ vs. $\mathrm{Ag} / \mathrm{AgCl} 9-\mathrm{MHz}$ triangular wave potential was applied to the microorganisms on the ITO electrode in fresh PBS(-) for $60 \mathrm{~min}$ at RT. High-frequency triangular wave potential induced detachment of soil microorganisms, E. coli, and B. subtilis from the ITO electrode after $60 \mathrm{~min}$ of application (Fig. 6a). Figure $6 \mathrm{~b}$ shows the time course of soil microorganism detachment from the reticulated ITO electrode region. Only PBS(-) treatment for $60 \mathrm{~min}$ did not detach the microorganisms from the electrode surface (Fig. 6b). A $\pm 10-\mathrm{mV}$ vs. $\mathrm{Ag} / \mathrm{AgCl} 9-\mathrm{MHz}$ triangular wave potential detached $66 \%$ of the soil microorganisms after $30 \mathrm{~min}$ of application, and almost all of the microorganisms were detached after $60 \mathrm{~min}$ of application (Fig. 6b). Under the experimental conditions shown in Fig. 6, we collected $3.0 \times 10^{9}$ cells $/ \mathrm{g}$ $\left(1.5 \times 10^{5}\right.$ cells $\left./ 50 \mu \mathrm{g}\right)$ of living microorganisms from the total $4.2 \times 10^{9}$ cells $/ g$ in the garden soil sample. Table 1 shows the viability of the microorganisms after highfrequency triangular wave potential application. The application of $\pm 10, \pm 6$, and $\pm 4 \mathrm{mV}$ vs. $\mathrm{Ag} / \mathrm{AgCl} 9$ - $\mathrm{MHz}$ triangular wave potential detached more than $98 \%$ of the microorganisms on the electrode surface after $60 \mathrm{~min}$ in PBS(-) at RT (Table 1). To examine the cytotoxicity of electrical detachment using the high-frequency triangular wave potential, we measured the survival rates of the residual microorganisms on the electrode surface after $60 \mathrm{~min}$ of application. High and low survival rates were $91 \%$ (517 of 566 cells) and $17 \%$ (120 of 726 cells) of soil microorganisms after \pm 10 and $\pm 8 \mathrm{mV} 9-\mathrm{MHz}$ triangular wave potential application, respectively (Table 1). After $\pm 8 \mathrm{mV}$ triangular wave potential application for $60 \mathrm{~min}$, a large portion of the remaining microorganisms on the electrode surface was comprised of dead cells, and the detachment rate was lower than under the other experimental conditions (Table 1). In the cultured microorganisms, $83 \%$ ( 283 of 342 cells) of the E. coli and $47 \%$ (243 of 522 cells) of the B. subtilis cells remained alive after $60 \mathrm{~min}$ of application (Table 1). We also examined the viable bacteria collection rates of $E$. coli and $B$. subtilis by colony counting in the supernatants in the three-electrode chamber system (Table 1). We collected the supernatants of both after $24 \mathrm{~h}$ of application of the $-0.4 \mathrm{~V}$ vs. $\mathrm{Ag} / \mathrm{AgCl}$ potential and after $1 \mathrm{~h}$ of application of the high-frequency triangular wave potential. The viable bacteria collection rate was calculated from the colony number after high-frequency triangular wave potential application divided by the total colony number. The viable bacteria collection rates indicated similar survival rates (Table 1). We successfully recovered $88 \%$ (238 of 272 colony-forming units (CFU)) of E. coli and $48 \%$ (157 of $328 \mathrm{CFU}$ ) of B. subtilis from the cell suspensions using the electrical attachment and detachment techniques (Table 1).

\section{Electrical Collection of Microorganisms from Deep-Sea Sediment}

To determine which types of microorganism would attach to the electrode surface with a negative potential applied, we used a deep-sea sediment sample collected at a depth of $1,176 \mathrm{~m}$ in the seep area of Sagami Bay, Japan (Koyama and Aizawa 2000; Koyama et al. 2005). The microbial flora composition of the microorganisms electrically retrieved from the sediment samples was compared with that of the original sample by phylotype analysis of PCR-amplified 16S rRNA genes (Figs. 7 and 8). In the garden soil sample,

Table 1 Viability analyses of electrically detached microorganisms

\begin{tabular}{|c|c|c|c|c|}
\hline Sample $^{\mathrm{a}}$ & Triangular wave potential, $1 \mathrm{~h}$ at $\mathrm{RT}$ & Detachment rate $(\%)^{\mathrm{b}}$ & Survival rate $(\%)^{\mathrm{c}}$ & Viable bacteria collection rate $(\%)^{\mathrm{d}}$ \\
\hline Garden soil & $\pm 10 \mathrm{mV}, 9 \mathrm{MHz}$ & 99.8 & 91 & N. D. \\
\hline Garden soil & $\pm 8 \mathrm{mV}, 9 \mathrm{MHz}$ & 65.5 & 17 & N. D. \\
\hline Garden soil & $\pm 6 \mathrm{mV}, 9 \mathrm{MHz}$ & 99.8 & 58 & N. D. \\
\hline Garden soil & $\pm 4 \mathrm{mV}, 9 \mathrm{MHz}$ & 98 & 38 & N. D. \\
\hline E. coli & $\pm 10 \mathrm{mV}, 9 \mathrm{MHz}$ & 99.6 & 83 & 88 \\
\hline B. subtilis & $\pm 10 \mathrm{mV}, 9 \mathrm{MHz}$ & 99.7 & 47 & 48 \\
\hline
\end{tabular}

N. D. not determined

${ }^{\mathrm{a}}$ Each microorganism in $\mathrm{PBS}(-)$ selectively attached to the reticulated ITO electrode region to which $-0.4 \mathrm{~V}$ vs. $\mathrm{Ag} / \mathrm{AgCl}$ potential was applied for $24 \mathrm{~h}$ at RT. Then, $\pm 10 \mathrm{mV}$ vs. $\mathrm{Ag} / \mathrm{AgCl} 9-\mathrm{MHz}$ triangular wave potential was applied for $1 \mathrm{~h}$ at $\mathrm{RT}$

${ }^{\mathrm{b}}$ Cell numbers were counted in randomly selected $50 \times 50-\mu \mathrm{m}^{2}$ regions of the reticulated ITO electrode region before and after triangular wave potential application

${ }^{\mathrm{c}}$ More than 300 residual microorganisms on the electrodes were distinguished using a live/dead backlight bacterial viability kit after electrical detachment. Survival rates were determined by the sum of three independent experiments

${ }^{\mathrm{d}}$ The viable bacteria collection rate was calculated from colony numbers after triangular wave potential application divided by the total colony number. Collection rates were determined by the sum of three independent experiments 
a

b

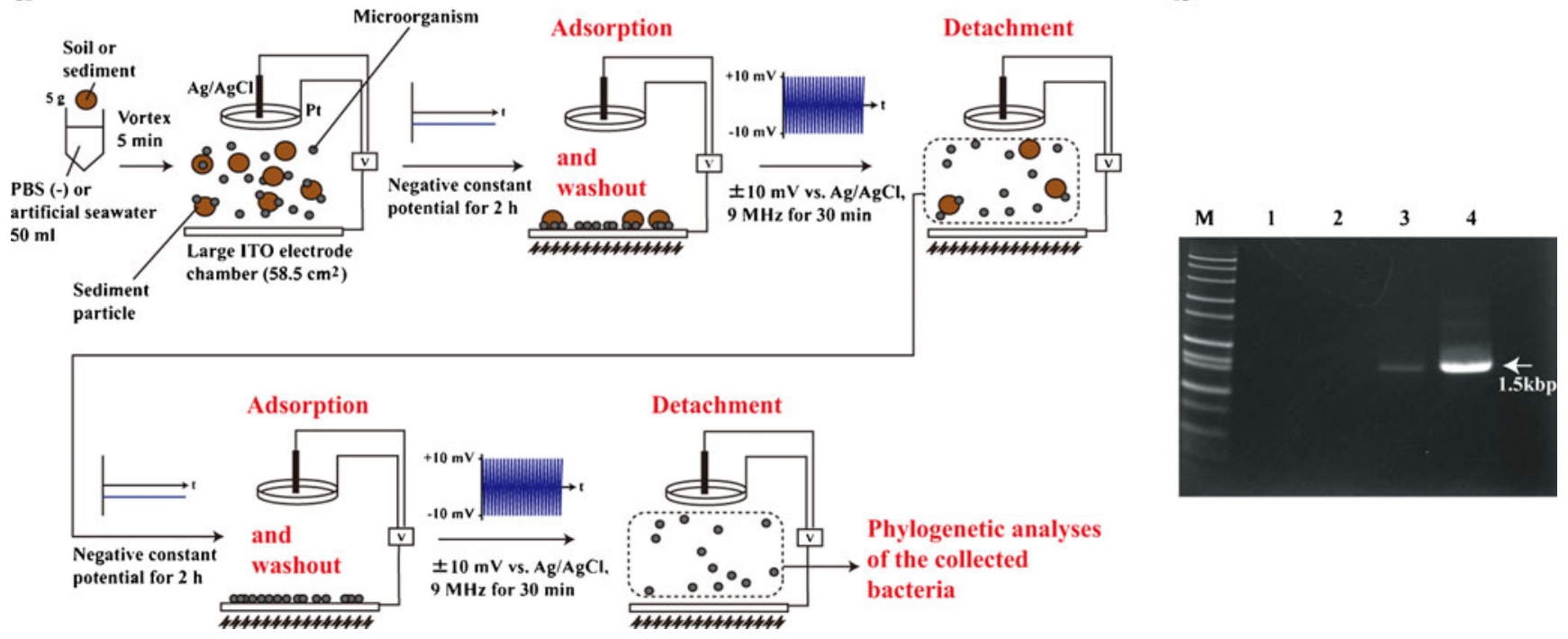

Fig. 7 Electrical retrieval method for soil or sediment microorganisms. a Schematic illustration of the electrical retrieval method for soil or sediment microorganisms. b PCR products from the garden soil samples before purification of phylogenetic analyses. $M$ DNA marker, 1 negative control, 2 direct soil DNA extraction, 3 first electrically retrieved microorganisms derived DNA, 4 second electrically retrieved microorganisms derived DNA

\section{Direct sediment DNA extraction $(n=136)$}

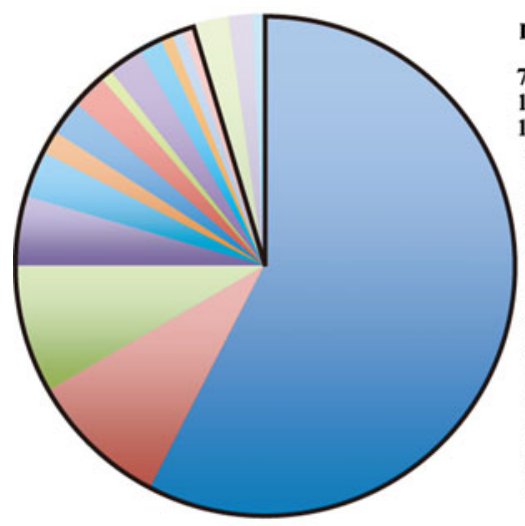

n Phylum
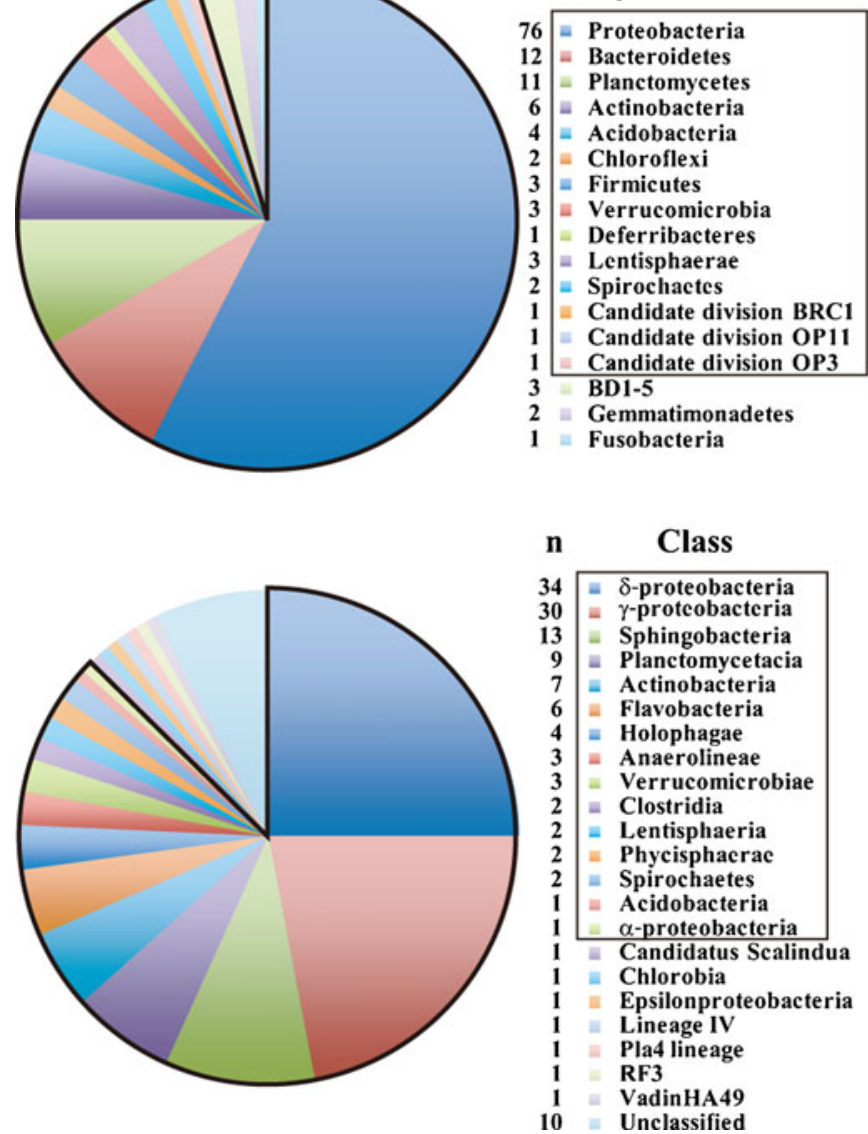

Electrically retrieved bacteria $(n=132)$
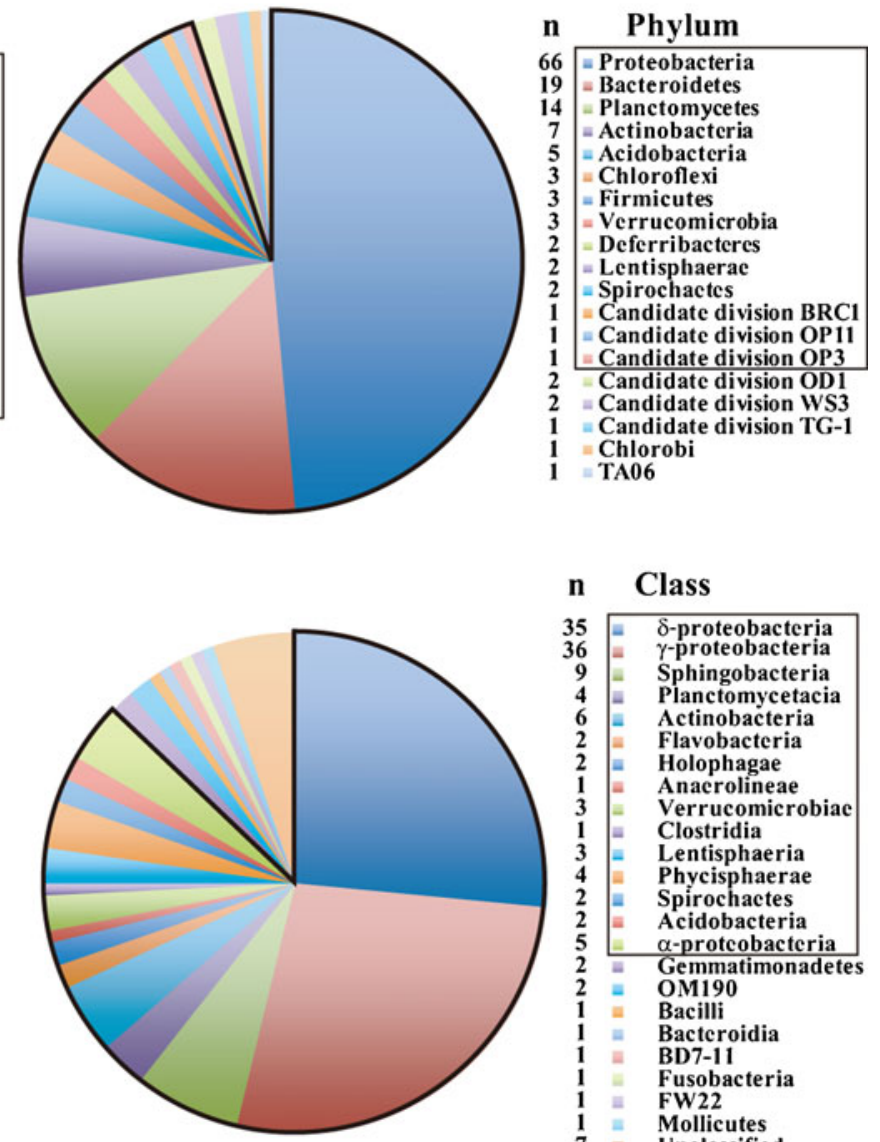

Fig. 8 Phylogenetic affiliation of strains isolated from deep-sea sediment. The outlined regions indicate common phylotypes between direct sediment DNA extraction and electrically retrieved bacteria 
no PCR amplicon was obtained from the DNA directly extracted from the soil sample (Fig. 7). The PCR may be inhibited by humic substances in the soil (Roh et al. 2006), and therefore the microbial flora in the electrically retrieved garden soil microorganisms and DNA directly extracted from the soil sample could not be compared (Fig. 7). Figure 7a shows the method used for electrical retrieval of microorganisms from the deep-sea sediment samples for phylogenetic analyses. To determine the microbial composition from the sediment sample, the electrical retrieval of microorganisms was performed twice using the large electrode chamber devices (Fig. 7a). Moreover, both the constant and high-frequency triangular potential application times were shortened (Fig. 7a). After the procedures shown in Fig. $7 \mathrm{a}$, we obtained $1.3 \times 10^{8}$ microorganisms from the 5g deep-sea sediment sample. Figure 8 compares the microbial community structure of the deep-sea sediment after electrical retrieval method and direct sediment DNA extraction. Deep-sea microorganisms belonging to 19 phyla and 23 classes were obtained using the electrical retrieval method (Fig. 8). The majority of the retrieved clones obtained with the electrical retrieval method were affiliated with Proteobacteria (Fig. 8). The remaining phyla were affiliated with Bacteroidetes, Planctomycetes, Actinobacteria, Acidobacteria, Chloroflexi, Firmicutes, Verrucomicrobia, Deferribacteres, Lentisphaerae, Spirochaetes, Candidate division BRC1, OP11, OP3, OD1, WS3, TG-1, Chlorobi, and TA06 groups (Fig. 8). At the phylum level $95 \%$ and at the class level $87 \%$ of the phylotypes among electrically retrieved bacteria were common to the gene clones from the direct sediment DNA extraction (Fig. 8). The results in Fig. 8 indicate that the electrical retrieval method collected a broad range of living microorganisms, which may reflect the organization of the microbial community in the sediment sample.

\section{Discussion}

In this study, we demonstrated that an extensive range of living bacteria attached to the electrode surface with a negative applied potential in non-nutritive media. This result was supported by the E. coli attachment results (Fig. 2); the AFM and SEM images of E. coli (Fig. 3); the B. subtilis, $B$. halodurans, $K$. rosea, $S$. violacea, $S$. oneidensis, and soil microorganism attachment results (Figs. 4 and 5); and the determination of the deep-sea microbial community structure (Fig. 8). Nineteen phyla and 23 classes of microorganisms in deep-sea sediment samples were collected using the electrical attachment and detachment methods (Fig. 8). The electrical retrieval method collected almost all of the bacterial phylotypes detected using the direct DNA extraction method (Fig. 8). Furthermore, the electrical modulation of the spatial configuration of $E$. coli cells was also successful using ITO microelectrodes (Fig. 3). These techniques hold potential for novel microbial metagenomic analyses.

The results in Figs. 2, 3, 4, and 8 suggest that the ITO electrode region with a negative applied potential acts as an energy source for a broad range of microorganisms. It appears that microorganisms such as E. coli, B. subtilis, $B$. halodurans, $K$. rosea, $S$. violacea, and $S$. oneidensis produce adherent short fibrous materials in response to contact with the electrode surface with a negative applied potential (Figs. 2, 3, and 4). We observed a weak electrical current of -0.19 to $-0.88 \mu \mathrm{A} / \mathrm{cm}^{2}$ when a negative constant potential between -0.3 - and $-0.4 \mathrm{~V}$ vs. $\mathrm{Ag} / \mathrm{AgCl}$ was applied to cultured microorganisms and soil and sediment samples. The pili of Geobacter sulfurreducens may serve as biological nanowires, transferring electrons from the cell surface to the surface of Fe(III) oxides (Reguera et al. 2005). S. oneidensis nanowires were found to be electrically conductive along micrometer-length scales, with a measured resistivity on the order of $1 \Omega \mathrm{cm}$ (El-Naggar et al. 2010). Electron donors are often called energy sources because energy is released when they are oxidized (Madigan and Martinko 2006). Therefore, an electrode with a negative applied potential per se may act as an electron donor that is available for a variety of microorganisms. If the electrode acts as an electron donor in $\operatorname{PBS}(-)$, oxygen would be an electron acceptor (Fig. 2). Under anaerobic and PBS(-) conditions, the maximum attached E. coli cell density was increased (Fig. 2b, c). To obtain the anaerobic conditions, we used the anaerobic cultivation system that maintained $5 \%$ carbon dioxide and less than $1 \%$ oxygen concentrations after $60 \mathrm{~min}$ of cultivation. Although the $E$. coli cell density was enhanced in $\operatorname{PBS}(-)$, no statistically significant differences between the $-0.4 \mathrm{~V}$ vs. $\mathrm{Ag} / \mathrm{AgCl}$ application and the open circuit were observed in $280 \mathrm{mM}$ glucose under both aerobic and anaerobic conditions (Fig. 2b, c). Therefore, the microorganisms attached on the negative potential applied electrode surface might synthesize a part of microbial components from carbon dioxide. The -0.3 and $-0.4 \mathrm{~V}$ vs. $\mathrm{Ag} / \mathrm{AgCl}$ negative potentials correspond to -0.1 and $-0.2 \mathrm{~V}$ of reduction potentials $\left(E_{0}{ }^{\prime}\right)$, respectively. If the microorganisms on the negative potential applied electrode induce carbon dioxide fixation, energy supply of ATP molecules would be needed for the fixation reactions because of the low reduction potentials of the electrode (Madigan and Martinko 2006). Further research will determine the mechanisms on how the negative potential induced a wide range of the microorganism attachments. The electrical retrieval method could be used not only for microorganism extraction from soil and sediment samples but also for symbiotic bacteria extraction from biological samples. The electrical modulation method would also expand applications of the microbial battery and sensor in diverse ways.

In our previous study using animal cells, we found that $\pm 10-\mathrm{mV}$ vs. $\mathrm{Ag} / \mathrm{AgCl} 9-\mathrm{MHz}$ triangular wave potential 
induced detachment of both animal cells and extracellular matrix proteins (Koyama 2011). The mechanism of detachment involved both oscillation of the negative zeta potentialcharged animal cells and the insertion of water molecules between the electrode surface and extracellular matrix proteins resulting from increments in hydrophilicity on the electrode surface (Koyama 2011). Because the triangular wave potential oscillated and detached the negative zeta potential-charged cells, potential application of optimal wave shape, optimal resonance frequency, and optimal amplitude in each phylotype of microorganism would shorten the time to detachment and retrieval of living microorganisms from the electrode (Fig. 6; Table 1).

Acknowledgments This study was partly supported by a Grant-inAid for Exploratory Research (No. 23658085) from the Ministry of Education, Culture, Sports, Science and Technology of Japan.

Open Access This article is distributed under the terms of the Creative Commons Attribution License which permits any use, distribution, and reproduction in any medium, provided the original author(s) and the source are credited.

\section{References}

Ashelford KE, Chuzhanova NA, Fry JC, Jones AJ, Weightman AJ (2006) New screening software shows that most recent large 16S rRNA gene clone libraries contain chimeras. Appl Environ Microbiol 72:5734-5741

Bayer ME, Sloyer JL Jr (1990) The electrophoretic mobility of gramnegative and gram-positive bacteria: an electrokinetic analysis. J Gen Microbiol 136:867-874

Bergquist PL, Hardiman EM, Ferrari BC, Winsley T (2009) Applications of flow cytometry in environmental microbiology and biotechnology. Extremophiles 13:389-401

Bershtein S, Tawfik DS (2008) Advances in laboratory evolution of enzymes. Curr Opin Chem Biol 12:151-158

Brehm-Stecher BF, Johnson EA (2004) Single-cell microbiology: tools, technologies, and applications. Microbiol Mol Biol Rev 68:538-559

Broude NE (2011) Analysis of RNA localization and metabolism in single live bacterial cells: achievements and challenges. Mol Microbiol 80:1137-1147

Button DK, Schut F, Quang P, Martin R, Robertson BR (1993) Viability and isolation of marine bacteria by dilution culture: theory, procedures, and initial results. Appl Environ Microbiol 59:881-891

Courtois S, Frostegård A, Göransson P, Depret G, Jeannin P, Simonet P (2001) Quantification of bacterial subgroups in soil: comparison of DNA extracted directly from soil or from cells previously released by density gradient centrifugation. Environ Microbiol 3:431-439

Ebersole RC, McCormick RM (1993) Separation and isolation of viable bacteria by capillary zone electrophoresis. Biotechnology 11:1278-1282

El-Naggar MY, Wanger G, Leung KM, Yuzvinsky TD, Southam G, Yang J, Lau WM, Nealson KH, Gorby YA (2010) Electrical transport along bacterial nanowires from Shewanella oneidensis MR-1. Proc Natl Acad Sci USA 107:18127-18131

Frederiks WM, van Marle J, van Oven C, Comin-Anduix B, Cascante M (2006) Improved localization of glucose-6-phosphate dehydrogenase activity in cells with 5-cyano-2,3-ditolyl-tetrazolium chloride as fluorescent redox dye reveals its cell cycle-dependent regulation. J Histochem Cytochem 54:47-52

Fröhlich J, König H (2000) New techniques for isolation of single prokaryotic cells. FEMS Microbiol Rev 24:567-572

Fu AY, Spence C, Scherer A, Arnold FH, Quake SR (1999) A microfabricated fluorescence-activated cell sorter. Nat Biotechnol 17:1109-1111

Gabor EM, de Vries EJ, Janssen DB (2003) Efficient recovery of environmental DNA for expression cloning by indirect extraction methods. FEMS Microbiol Ecol 44:153-163

Hatada Y, Mizuno M, Li Z, Ohta Y (2011) Hyper-production and characterization of the l-carrageenase useful for l-carrageenan oligosaccharide production from a deep-sea bacterium, Microbulbifer thermotolerans JAMB-A94T, and insight into the unusual catalytic mechanism. Mar Biotechnol 13:411-422

Hiraishi A, Yoshida N (2004) An improved redox dye-staining method using 5-cyano-2,3-ditoryl tetrazolium chloride for detection of metabolically active bacteria in activated sludge. Microbes Environ 19:61-70

Horikoshi K, Akiba T (1982) Alkalophilic microorganisms: a new microbial world. Springer, New York

Hu X, Bessette PH, Qian J, Meinhart CD, Daugherty PS, Soh HT (2005) Marker-specific sorting of rare cells using dielectrophoresis. Proc Natl Acad Sci USA 102:15757-15761

Huber R, Huber H, Stetter KO (2000) Towards the ecology of hyperthermophiles: biotopes, new isolation strategies and novel metabolic properties. FEMS Microbiol Rev 24:615-623

Ishii S, Tago K, Senoo K (2010) Single-cell analysis and isolation for microbiology and biotechnology: methods and applications. Appl Microbiol Biotechnol 86:1281-1292

Kato C, Sato T, Horikoshi K (1995) Isolation and properties of barophilic and barotolerant bacteria from deep-sea mud samples. Biodiv Conserv 4:1-9

Koyama S, Aizawa M (2000) Tissue culture of the deep-sea bivalve Calyptogena soyoae. Extremophiles 4:385-389

Koyama S, Nagahama T, Ootsu N, Takayama T, Horii M, Konishi S, Miwa T, Ishikawa Y, Aizawa M (2005) Survival of deep-sea shrimp (Alvinocaris sp.) during decompression and larval hatching at atmospheric pressure. Mar Biotech 7:272-278

Koyama S (2011) Electrically modulated attachment and detachment of animal cells cultured on an optically transparent patterning electrode. J Biosci Bioeng 111:574-583, erratum in J Biosci Bioeng 114:240-241 (2012)

Lane DJ, Pace B, Olsen GJ, Stahl DA, Sogin ML, Pace NR (1985) Rapid determination of $16 \mathrm{~S}$ ribosomal RNA sequences for phylogenetic analyses. Proc Natl Acad Sci USA 82:6955-6959

Link AJ, Jeong KJ, Georgiou G (2007) Beyond toothpicks: new methods for isolating mutant bacteria. Nat Rev Microbiol 5:680-688

Madigan MT, Martinko JM (2006) Brock biology of microorganisms, 11 th edn. Pearson Education, New Jersey

Ohta Y, Hatada Y (2006) A novel enzyme, lambda-carrageenase, isolated from a deep-sea bacterium. J Biochem 140:475-481

Raaijmakers JM, Weller DM, Thomashow LS (1997) Frequency of antibiotic-producing Pseudomonas spp. in natural environments. Appl Environ Microbiol 63:881-887

Rajendhran J, Gunasekaran P (2008) Strategies for accessing soil metagenome for desired applications. Biotechnol Adv 26:576-590

Reguera G, McCarthy KD, Mehta T, Nicoll JS, Tuominen MT, Lovley DR (2005) Extracellular electron transfer via microbial nanowires. Nature 435:1098-1101

Roh C, Villatte F, Kim BG, Schmid RD (2006) Comparative study of methods for extraction and purification of environmental DNA from soil and sludge samples. Appl Biochem Biotechnol 134:97-112

Schut F, de Vries EJ, Gottschal JC, Robertson BR, Harder W, Prins RA, Button DK (1993) Isolation of typical marine bacteria by 
dilution culture: growth, maintenance, and characteristics of isolates under laboratory conditions. Appl Environ Microbiol 59:2150-2160

Shen B, Du L, Sanchez C, Edwards DJ, Chen M, Murrell JM (2001) The biosynthetic gene cluster for the anticancer drug bleomycin from Streptomyces verticillus ATCC15003 as a model for hybrid peptide-polyketide natural product biosynthesis. J Ind Microbiol Biotechnol 27:378-385

Skoko N, Vujovic J, Savic M, Papic N, Vasiljevic B, Ljubijankic G (2005) Construction of Saccharomyces cerevisiae strain FAV20 useful in detection of immunosuppressants produced by soil actinomycetes. J Microbiol Methods 61:137-140

Simon C, Daniel R (2011) Metagenomic analyses: past and future trends. Appl Environ Microbiol 77:1153-1161

Steffan RJ, Goksøyr J, Bej AK, Atlas RM (1988) Recovery of DNA from soils and sediments. Appl Environ Microbiol 54:2908-2915

Takami H, Horikoshi K (1999) Identification of facultatively alkaliphilic Bacillus sp. C-125 to Bacillus halodurans. Biosci Biotechnol Biochem 63:943-945 